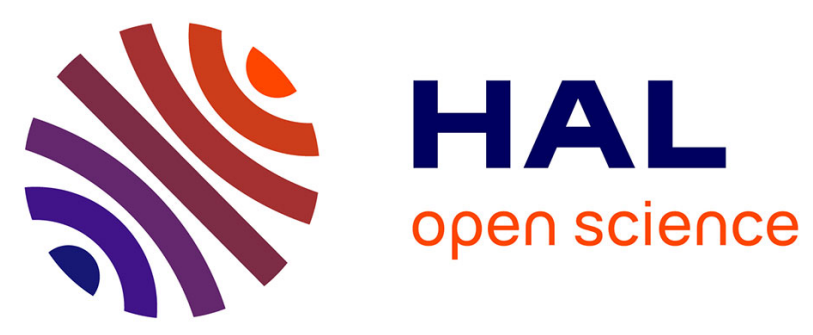

\title{
Diastereoselective synthesis of axially chiral xylose-derived 1,3-disubstituted alkoxyallenes: scope, structure and mechanism
}

Moustapha Fortunato, Yves Gimbert, Elodie Rousset, Pedro Lameiras, Agathe Martinez, Sylvain Gatard, Richard Plantier-Royon, Florian Jaroschik

\section{To cite this version:}

Moustapha Fortunato, Yves Gimbert, Elodie Rousset, Pedro Lameiras, Agathe Martinez, et al.. Diastereoselective synthesis of axially chiral xylose-derived 1,3-disubstituted alkoxyallenes: scope, structure and mechanism. Journal of Organic Chemistry, 2020, 10.1021/acs.joc.0c01240 . hal-02919423

\section{HAL Id: hal-02919423 \\ https://hal.science/hal-02919423}

Submitted on 22 Aug 2020

HAL is a multi-disciplinary open access archive for the deposit and dissemination of scientific research documents, whether they are published or not. The documents may come from teaching and research institutions in France or abroad, or from public or private research centers.
L'archive ouverte pluridisciplinaire HAL, est destinée au dépôt et à la diffusion de documents scientifiques de niveau recherche, publiés ou non, émanant des établissements d'enseignement et de recherche français ou étrangers, des laboratoires publics ou privés. 


\title{
Diastereoselective synthesis of axially chiral xylose-derived 1,3-disubstituted alkoxyallenes: scope, structure and mecha- nism
}

\author{
Moustapha Fortunato,§ Yves Gimbert,*匹 Elodie Rousset, § Pedro Lameiras, § Agathe Martinez, § Sylvain \\ Gatard, ${ }^{*}$ Richard Plantier-Royon, ${ }^{*}$ and Florian Jaroschik* \\ §Institut de Chimie Moléculaire de Reims, UMR CNRS 7312, Université de Reims Champagne-Ardenne, 51687 Reims, \\ France
}

I Département de Chimie Moléculaire, UMR CNRS 5250, Université Grenoble Alpes, 38058 Grenoble, France

‡ICGM, Université de Montpellier, ENSCM, 34090 Montpellier, France

\begin{abstract}
The deprotonation of differently substituted propargyl xylosides with $s$-BuLi/TMEDA followed by protonation with $t$-butanol at $-115^{\circ} \mathrm{C}$ provided a range of new axially chiral 1,3-disubstituted alkoxyallenes in a diastereoselective way. Numerous reaction parameters such as solvent, temperature or protonating agent were examined as well as protecting groups on the xyloside moiety and the influence of the substituents on the alkyne part. The configuration of the main diastereoisomer of 3-methyl-1-xyloside-allene was determined for the first time by single crystal X-ray diffraction analysis and nOe NMR experiments. Furthermore, DFT calculations on the propargyl/allenyl lithium intermediates formed in the course of the deprotonation reaction provided new structural insights of these complexes. The subsequent protonation process with alcohols was investigated by theoretical surface exploration, revealing the importance of the approach of the alcohol towards the lithium compounds on the reaction outcome.
\end{abstract}

\section{Introduction}

In recent years, the number of applications of allenes as building blocks in organic synthesis has considerably increased due to their unique properties. ${ }^{1}$ Indeed, their reactivity and their intrinsic chirality make them the precursors of choice to access more complex molecules such as heterocycles or natural products. ${ }^{2}$ Therefore, there is an increasing need for efficient synthetic methodologies to access axially chiral allenes in an enantioor diastereoselective manner. ${ }^{3}$ Among the recently developed procedures, only very few studies were dedicated to the synthesis of diastereomerically enriched alkoxyallenes, ${ }^{4}$ a widely employed class of allenes. ${ }^{2 e, 5}$ The applied strategy used chiral auxiliaries, however, the scope remained restricted to 1,3-disubstituted allenes bearing alkyl substituents, hence limiting more molecular complexity. For instance, the groups of Tius 4 a and Reissig4b,c, respectively, reported the highly diastereoselective synthesis of some 1,3-disubstituted alkoxyallenes using fructose- or camphor-derived chiral auxiliaries in the well-known metal-mediated isomerization $^{1 \mathrm{a}, \mathrm{b}}$ of propargyl ethers (Scheme 1).
Scheme 1. Synthetic access to diastereomerically enriched 1,3-disubstituted alkoxyallenes.
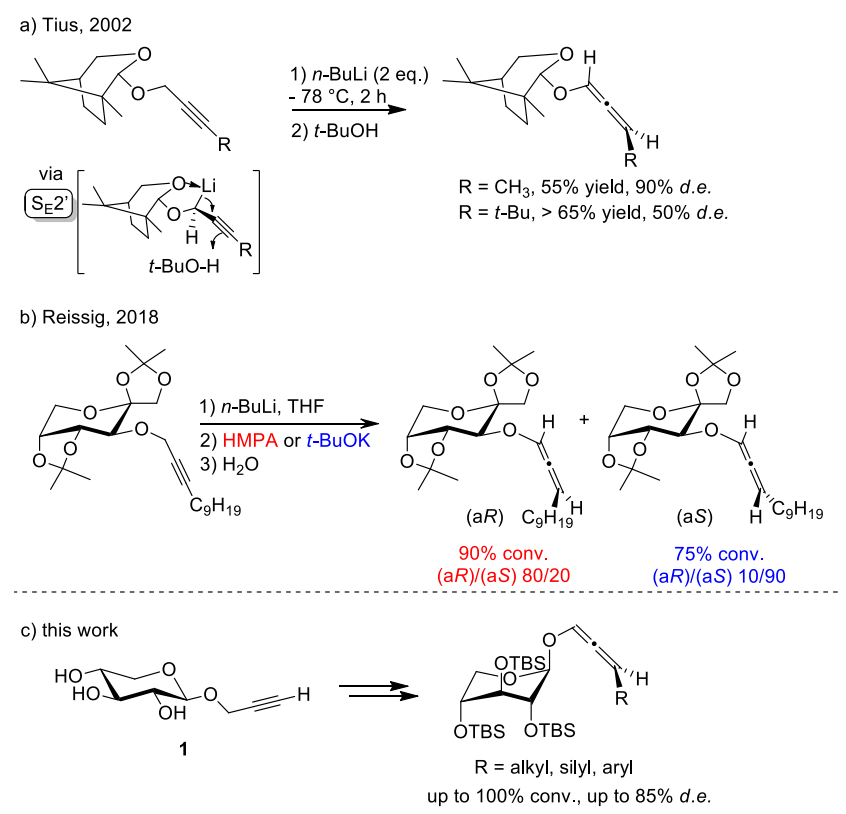

To rationalize the observed selectivities, several aspects must be considered. These reactions usually op- 
erate via a two-step mechanism (Scheme 2). First, a basic treatment in the presence of an organolithium reagent yields the Li-propargyl (P)/Li-allenyl (A) intermediates in equilibrium. Then, the protonation of this metallotropic equilibrium leads to a mixture of regio- and diastereoisomers. The protonation step can proceed either by a $S_{E} 2$ or a $S_{E} 2$ ' type mechanism. The regio- and stereoselectivity of these reactions depend on a certain number of parameters including the solvent, the temperature and the metal, as well as the transition states of the reaction and the rate constants.

Scheme 2. Metallotropic equilibrium between generally proposed Li-propargyl and Li-allenyl intermediates and protonation pathways.

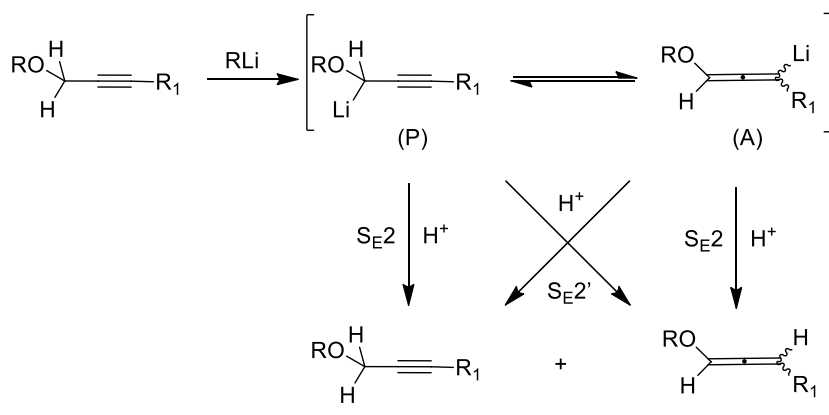

In the case of Reissig's work, ${ }^{4 b, c}$ the addition of HMPA or $t$-BuOK to the Li-propargyl/Li-allenyl intermediates in equilibrium led to the formation of considerably more basic separated ion pairs and proton migration to form allenyl carbanions with fixed configurations. The subsequent protonation occurred via a $\mathrm{S}_{\mathrm{E}} 2$ mechanism to yield the diastereoisomers $(\mathrm{a} R)$ or $(\mathrm{a} S)$ with high conversion and good diastereomeric ratio (d.r.), depending on the additive (Scheme 1b). On the other hand, Tius suggested an assistance of the chiral auxiliary to selectively deprotonate the pro- $S$ propargylic proton leading to the chelation of the cyclic oxygen of camphor to the lithium atom to stabilize the Li-propargyl (P) intermediate (without considering the usual Lipropargyl/Li-allenyl equilibrium). This would give access to the corresponding allene via a $\mathrm{S}_{\mathrm{E}} 2$ ' mechanism (Scheme 1a).4a These examples leave open a certain number of questions concerning the different stages of this mechanism, in particular on the existence of an equilibrium between the lithiated species and its influence on the regio- and the diastereoselectivity observed, but also on the role of the proton source in the process. As part of our work dedicated to the development of new chemical or enzymatic transformation pathways for pentoses from lignocellulosic biomass, ${ }^{6}$ we herein report on the diastereoselective synthesis of 1,3-disubstituted alkoxyallenes ( $\mathrm{R}=$ alkyl, aryl, silyl) from propargyl xyloside $\mathbf{1}^{7}$ Despite the high natural abundance of D-xylose in plants, ${ }^{8}$ only few examples have been reported on the use of its intrinsic chirality for stereoselective processes. ${ }^{9}$ One of the advantages of using this sugar moiety as a chiral auxiliary in this isomerization reaction lies in the presence of oxygen atoms with different spatial arrangements which have the capacity to coordinate lithium to promote the formation of the Li-propargyl/allenyl intermediates stabilized in a defined configuration. In order to provide further synthetic insights and gain a better understanding on the underlying reaction mechanisms, we explored the influence of protecting groups on the sugar moiety and the alkyne substituents on the structural parameters of the Li-propargyl (P)/allenyl (A) intermediates in equilibrium and studied the protonation pathways during the isomerization step by DFT studies. It should be noted that Reich and co-workers have extensively studied the structures and the equilibrium between Li-propargyl (P)/allenyl (A) species for a range of alkyl and silyl substituted compounds.[10] However, this is the first report on a detailed study with alkoxy derivatives.

\section{Results and Discussion}

Synthesis of various substituted propargyl xylosides 3a-f from 1. Propargyl $\beta$-D-xylopyranoside $\mathbf{1}$ can be obtained either by a classical three-step chemical sequence from D-xylose or through an enzymatic transglycosylation process directly from beechwood xylans and propargyl alcohol. ${ }^{6 c, 11}$ The fully TBS protected propargyl xyloside 2 was readily prepared in up to $91 \%$ yield from 1 by reaction with $t$-butyldimethylsilyl chloride (TBS-Cl) in presence of imidazole and a catalytic amount of DMAP (Scheme 3) after heating at $80^{\circ} \mathrm{C}$ for 6 days. ${ }^{5 b}$ Lower temperatures or shorter reaction times led to the formation of product mixtures containing diand triprotected xylosides. Introduction of substituents on the alkyne was carried out via deprotonation and nucleophilic substitution for alkyl or silyl groups leading to $\mathbf{3 a}, \mathbf{b}$ or Pd-catalyzed Sonogashira ${ }^{12}$ coupling for aryl groups providing 3c-e in good to excellent yields. The $t$-butyl substituted compound 3f could not be obtained by these pathways, but via a 4-step procedure from D-xylose (see S1 in SI).

Scheme 3. Synthesis of various propargyl xylosides 2 and 3a-e. 


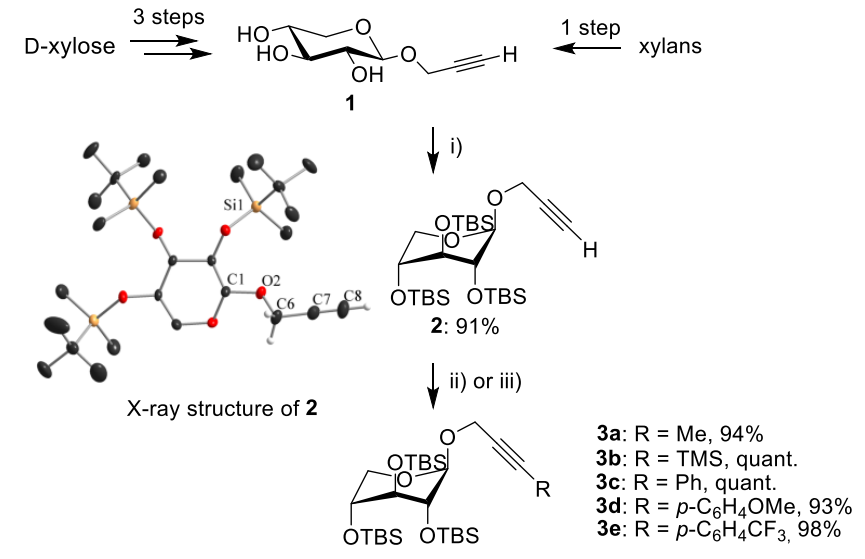

i) Imidazole (5 eq.), TBSCI (4 eq.), DMAP cat., DMF, $80{ }^{\circ} \mathrm{C}$; ii) $n$-BuLi (2 eq.), TMSCl or Mel (2 eq.), THF, $-78^{\circ} \mathrm{C}->$ r.t., 14 h; iii) $\mathrm{Arl}\left(1.1\right.$ eq.), $\mathrm{Pd}\left(\mathrm{PPh}_{3}\right)_{4}$ ( 0.005 eq.), Cul (0.01 eq.), $\mathrm{Et}_{3} \mathrm{~N} / \mathrm{THF}, 55^{\circ} \mathrm{C}, 24 \mathrm{~h}$.

Structural characterization of 2 and 3a. A pseudoaxial conformation of the silylated groups for compounds 2 and 3a-f was revealed by ${ }^{1} \mathrm{H}$ NMR. ${ }^{11 a, 13}$ Small coupling constants between 3.0 and $4.0 \mathrm{~Hz}$ were usually obtained for the ring protons of these compounds, showing a 1,2-trans-diaxial relationship between the silyl groups. For comparison, the unprotected xyloside 1 with the $\mathrm{OH}$ groups in equatorial position, showed values of 7.5 to $9.0 \mathrm{~Hz}$ for the analogous coupling constants (see Table S2).

To better analyse the preferred conformation of the silyl groups of the pyranosic cycle, ${ }^{1} \mathrm{H}$ NMR spectra of 2 and $\mathbf{3 a}$ in toluene- $\mathrm{d}_{8}$ and in THF- $\mathrm{d}_{8}$ were recorded at different temperatures between $-40{ }^{\circ} \mathrm{C}$ and $+70{ }^{\circ} \mathrm{C}$ and the values for ${ }^{3} J_{1,2}$ for each temperature are reported in Table 1. Decreasing the temperature from r.t. to $-40{ }^{\circ} \mathrm{C}$, the ${ }^{3} J_{1.2}$ coupling constants gradually increased to values above $6.0 \mathrm{~Hz}$ indicating an equatorial positioning of the silylated groups. On the other hand, increasing the temperature up to $70{ }^{\circ} \mathrm{C}$ led to a decrease of the ${ }^{3} J_{1.2}$ values towards $3.0 \mathrm{~Hz}$, showing the preference of the OTBS groups for a pseudo-axial conformation. These results clearly evidence the influence of the temperature on the conformational equilibrium of the TBS protected propargyl xylosides $\mathbf{2}$ and $\mathbf{3 a - f}$. It should be noted that variation in chemical shifts and differences in multiplicity were also observed at different temperatures, phenomena linked to the different conformations (see SI for the different ${ }^{1} \mathrm{H}$ NMR spectra recorded in toluene- $\mathrm{d}_{8}$ and $\mathrm{THF}-\mathrm{d}_{8}$ at different temperatures).

The molecular structure of $\mathbf{2}$ was determined in a solid-state X-ray diffraction study from single crystals obtained by slow evaporation of a concentrated petroleum ether solution at room temperature (Scheme 3). Unexpectedly, the structure revealed a conformation with an equatorial positioning of the silyl ether groups. Further crystallographic details are provided in the supporting information. The structure of $\mathbf{2}$ is a rare example of a terminal propargyl appended carbohydrate and the structural parameters compare well with the literature. ${ }^{14}$

In order to gain further insights on the conformational equilibrium in compound 3a with the OTBS groups in either axial or equatorial positions, DFT calculations were performed at the B3P86/6-31+G(d,p) level. No significant energetic difference between the optimised structures of the two conformations could be observed at room temperature $(\Delta \mathrm{G}(\mathrm{ax} / \mathrm{eq})=0.12 \mathrm{kcal} / \mathrm{mol})$ (see Table S3), hence a rapid equilibrium could be envisaged, leading to the crystallisation of the equatorial form, possibly due to packing effects.

Table 1. ${ }^{3} J_{1,2}$ values (in $\mathrm{Hz}$ ) observed in the ${ }^{1} \mathbf{H}$ NMR spectra (in toluene- $d_{8}$ and THF-d $d_{8}$ ) of 2 and 3a, recorded at different temperatures.

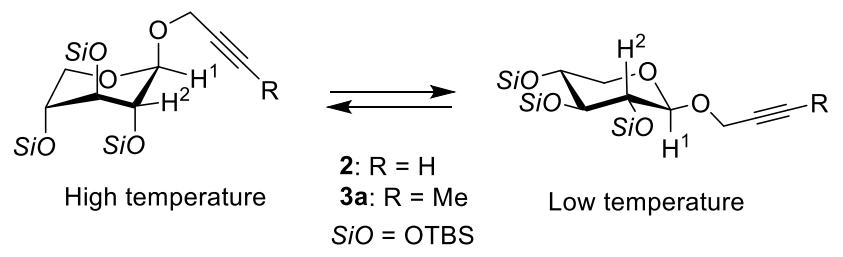

\begin{tabular}{cccc}
\hline $\mathrm{T}\left({ }^{\circ} \mathrm{C}\right)$ & $\begin{array}{c}{ }^{3} J_{1,2}(\mathrm{~Hz})^{[\mathrm{a}]} \\
\mathbf{2}\end{array}$ & $\begin{array}{c}{ }^{3} \mathrm{~J}_{1,2}(\mathrm{~Hz})^{[\mathrm{b}]} \\
\mathbf{2}\end{array}$ & $\begin{array}{c}{ }^{3} \mathrm{~J}_{1,2}(\mathrm{~Hz})^{[\mathrm{a}]} \\
\mathbf{3 a}\end{array}$ \\
\hline 70 & 3.2 & - & 3.3 \\
\hline 40 & 3.9 & 3.6 & 3.8 \\
\hline 25 & 4.0 & 4.1 & 3.8 \\
\hline-10 & 5.0 & 5.2 & 5.6 \\
\hline-20 & 5.4 & 5.6 & 6.1 \\
\hline-30 & 5.8 & 6.0 & 6.4 \\
\hline-40 & 6.1 & 6.4 & 6.8 \\
\hline [a]: determined in toluene- $\mathrm{d}_{8} ;[\mathrm{b}]:$ determined in THF- $\mathrm{d}_{8}$
\end{tabular}

Diastereoselective synthesis of a xylose-derived 1,3-disubstituted alkoxyallene. We then set out our studies on the synthesis of allene 4 a from the TBS protected 3-methyl substituted propargyl xyloside 3a. After deprotonation with 3 eq. $n$-BuLi in THF at $-78{ }^{\circ} \mathrm{C}$, the reaction was quenched at $-78{ }^{\circ} \mathrm{C}$ with $1 \mathrm{~N} \mathrm{HCl}$ to afford a 70:30 mixture of $\mathbf{3 a}$ and $\mathbf{4 a}$, however, with no diastereoselectivity for $4 \mathbf{a}$ (Scheme 4). ${ }^{4 \mathrm{~b}, \mathrm{c}}$ Interestingly, the ratio 3a to $4 a$ changed to $30: 70$ when the reaction was quenched at $-30{ }^{\circ} \mathrm{C}$, providing first evidence for an equilibrium between the Li-propargyl/allenyl intermediates. The ratios were determined by ${ }^{1} \mathrm{H}$ NMR spectroscopy in $\mathrm{CDCl}_{3}$ showing the appearance of the allenic protons $\left(\mathrm{H}_{3^{\prime}}\right)$ at $5.70 \mathrm{ppm}$ and $5.80 \mathrm{ppm}$ corresponding to the two diastereoisomers of allene $4 \mathbf{a}$. As in the case of propargyl derivatives 3a-f, small coupling constants 
between 4.0 and $5.0 \mathrm{~Hz}$ were observed for allene $4 \mathbf{a}$ indicating a privileged pseudo-axial conformation at room temperature (see SI for ${ }^{3} J_{1,2}$ values observed in the ${ }^{1} \mathrm{H}$ NMR spectra recorded at different temperatures).

Scheme 4. Conversion of propargyl xyloside 3a to allene 4a with $\mathrm{HCl}$ as the proton source.

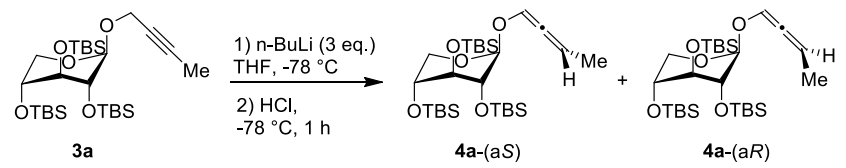

Inspired by the work of the group of Tius, ${ }^{4 a}$ we then switched to $t-\mathrm{BuOH}$ as the proton source (Table 2). Addition of $t-\mathrm{BuOH}$ to the lithiated compound at $-78{ }^{\circ} \mathrm{C}$ afforded $90 \%$ conversion to $\mathbf{4 a}$. However, only a modest 60:40 diastereoselectivity was observed (entry 1). Switching the solvent to diethyl ether and addition of equimolar amounts of TMEDA, with respect to $n-\mathrm{BuLi}$, provided a better 70:30 diastereoselectivity (entry 2). As previously mentioned, a decrease in temperature can increase the chirality transmission from the starting material, ${ }^{15}$ and the configurational stability of the organometallic species. ${ }^{16}$ Therefore, we performed the addition of $t$ - $\mathrm{BuOH}$ at $-115{ }^{\circ} \mathrm{C}$ to yield 4 a still with a good conversion but, at the same time, with even better stereoselectivity 93:7 (entry 3). The major diastereoisomer was isolated as a pure compound in $75 \%$ yield. Other solvents (hexanes or toluene) provided less satisfying results (entries 4 and 5). Finally, the amount of alkyllithium reagent could be reduced to 1.2 equivalent when $s$-BuLi was employed instead of $n$-BuLi (entry 6). Attempted transmetallation with $\mathrm{ZnBr}_{2}$ did not improve the outcome (entry 7). ${ }^{16}$ With the use of another chelating amine ligand, such as the chiral (+)-spartein ligand (entry 8), no conversion into the allene was observed. It should be noted that in the absence of TMEDA no reaction took place in diethyl ether.
Table 2. Optimisation studies for conversion of propargyl xyloside 3a to allene 4a using $t$-BuOH as the proton source.

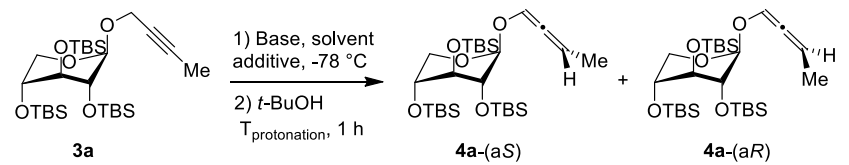

\begin{tabular}{|c|c|c|c|c|c|c|}
\hline Entry & $\begin{array}{l}\text { Base } \\
\text { (eq.) }\end{array}$ & Solvent & $\begin{array}{l}\mathrm{T}^{[\mathrm{a}]} \\
\left({ }^{\circ} \mathrm{C}\right)\end{array}$ & Additive & $\begin{array}{c}\text { Conv. }^{[\mathrm{b}]} \\
(\%)\end{array}$ & d.r. ${ }^{[b]}$ \\
\hline 1 & $\begin{array}{c}n \text {-BuLi } \\
\text { (3) }\end{array}$ & THF & -78 & - & 90 & $60: 40$ \\
\hline 2 & $\begin{array}{c}n \text {-BuLi } \\
\text { (3) }\end{array}$ & $\mathrm{Et}_{2} \mathrm{O}$ & -78 & TMEDA & 90 & $70: 30$ \\
\hline 3 & $\begin{array}{c}n \text {-BuLi } \\
\text { (3) }\end{array}$ & $\mathrm{Et}_{2} \mathrm{O}$ & -115 & TMEDA & 90 & $93: 7$ \\
\hline 4 & $\begin{array}{c}n \text {-BuLi } \\
\text { (3) }\end{array}$ & Toluene & -115 & TMEDA & 75 & $50: 50$ \\
\hline 5 & $\begin{array}{c}n \text {-BuLi } \\
\text { (3) }\end{array}$ & Hexanes & -115 & TMEDA & 55 & $67: 33$ \\
\hline 6 & $\begin{array}{c}\text { s-BuLi } \\
(1.2)\end{array}$ & $\mathrm{Et}_{2} \mathrm{O}$ & -115 & TMEDA & 90 & $93: 7$ \\
\hline 7 & $\begin{array}{c}\text { s-BuLi } \\
(1.2)\end{array}$ & $\mathrm{Et}_{2} \mathrm{O}$ & -115 & $\begin{array}{l}\text { TMEDA, } \\
\mathrm{ZnBr}_{2}\end{array}$ & 50 & $70: 30$ \\
\hline 8 & $\begin{array}{c}\text { s-BuLi } \\
(1.2)\end{array}$ & $\mathrm{Et}_{2} \mathrm{O}$ & -115 & $\begin{array}{c}(+)- \\
\text { sparteine }\end{array}$ & 0 & - \\
\hline
\end{tabular}

[a]: Protonation temperature; [b]: determined by ${ }^{1} \mathrm{H}$ NMR.

Determining the configuration of the major diastereoisomer of 4 a. In previous studies, the structure of the major diastereoisomer of allene was deduced from the stereochemistry of the products of consecutive transformations, e.g. Nazarov cyclisation ${ }^{4 a}$ or allene oxidation.4b In this study, we provide direct, analytical evidence for the elucidation of the configuration of the major isomer of $\mathbf{4 a}$. The presence of a bulky OTBS group in vicinity to the allenyl moiety encouraged us to carry out nOe NMR experiments to gain structural insights on the allene configuration. The nOe experiments carried out on a diastereomeric mixture of allenes 4a$(\mathrm{aS})$ and $4 \mathbf{a}-(\mathrm{a} R)$ showed that the $t$-Bu group of the OTBS group on the carbon in position 2 of the pyranosic cycle correlated both with the allenic proton $\mathrm{H}_{3}$ and the Me group linked to the allene function (for NMR spectra see SI). Interestingly, the correlation spots did not have the same intensity for each of the two diasteroisomers, indicating a closer distance between $\mathrm{H}_{3^{\prime}}$ and the $t$ - $\mathrm{Bu}$ group for the major diastereoisomer. In parallel, we carried out molecular modeling (B3P86/6-31+G(d,p) level) on the two diastereoisomers of allene $\mathbf{4 a}$, in order to determine the distances between the different groups. The distance calculated for $\mathbf{4 a -}(\mathrm{a} S)$ between the $t$ - $\mathrm{Bu}$ group was smaller with the proton $\mathrm{H}_{3^{\prime}}(5.23 \AA$, 
higher intensity for correlation task in NMR) than with the methyl group (Me) (5.69 $\AA$ ) (Figure 1; see SI for 4a$(\mathrm{a} R))$. From these results, we assigned the configuration $(\mathrm{a} S)$ for the major isomer.
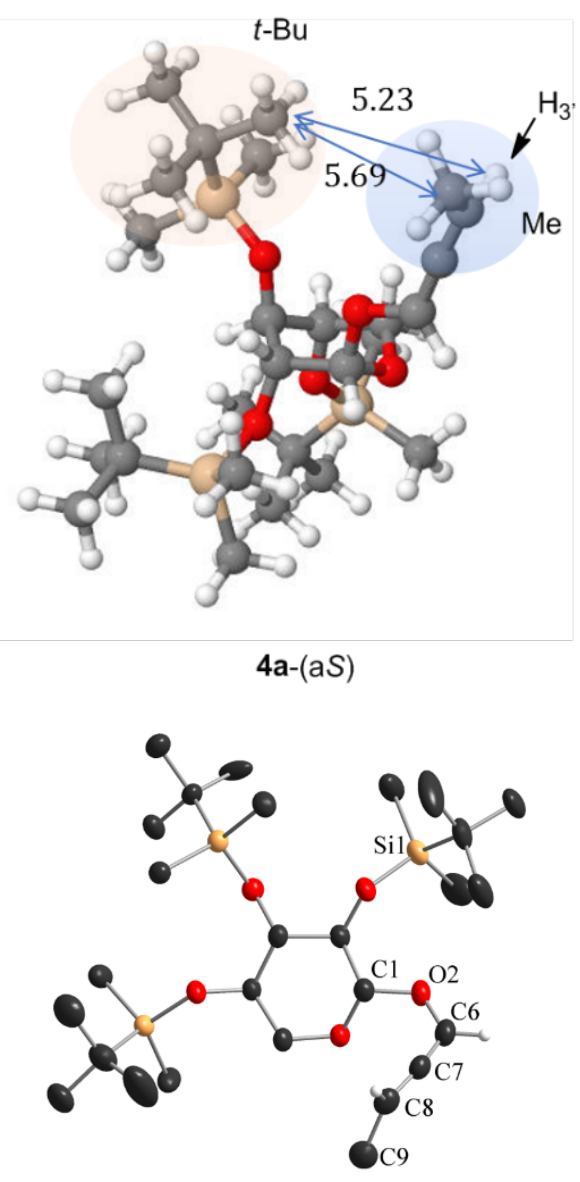

Figure 1. Above: Optimized structure of the major diastereoisomer 4a-(aS) with OTBS groups in axial position obtained by DFT calculations (B3P86/6-31+G(d,p) level) showing the distances (in $\AA$ ) between $\mathrm{H}_{3}$ ' and methyl group on allene with OTBS group. Below: Crystal structure of 4a- $(\mathrm{a} S)$ with OTBS groups in equatorial position. Ellipsoids are represented at $30 \%$ probability; hydrogen atoms are omitted for clarity, except for the allene hydrogens.

The absolute configuration of the major diastereoisomer 4a- $(\mathrm{a} S)$ was then confirmed by X-Ray diffraction studies. Single crystals were grown from a concentrated pentane solution at $0{ }^{\circ} \mathrm{C}$. The structure showed again the presence of all OTBS groups in the equatorial position, as per compound 2. Further crystallographic details are provided in the supporting information. The bond lengths and bond angles are in good agreement with the only other structurally characterized example of a sugar-based alkoxyallene, carrying a fructose fragment in that case. ${ }^{17}$ Interestingly, DFT calculations on 4a with the OTBS groups in axial or equatorial position, show a slight preference for their axial positioning at room temperature $(\Delta \mathrm{G}(\mathrm{ax} / \mathrm{eq})$ for $\mathbf{4 a}-(\mathrm{a} S)=-3.5$ $\mathrm{kcal} / \mathrm{mol} ; \Delta \mathrm{G}(\mathrm{ax} / \mathrm{eq})$ for $4 \mathrm{a}-(\mathrm{a} R)=-2.3 \mathrm{kcal} / \mathrm{mol}$ ) (see
Table S3), in agreement with the NMR data. However, an equilibrium still exists leading to the crystallization of the product with the silylated groups in equatorial position.

Evidence and study of the metallotropic equilibrium. To evidence a deprotonation step driving to a metallotropic equilibrium between $\mathrm{Li}$ propargyl/allenyl intermediates during the process of the formation of the allenes $4 \mathbf{a}-(\mathrm{a} S)$ and $4 \mathbf{a}-(\mathrm{a} R)$, the same reaction was carried out using $t$-BuOD instead of $t$-BuOH (Scheme 5). Deuterated allene 4a-(aS)-D was obtained with high conversion (90\%) and d.r. (90:10). Moreover, propargyl xyloside 3a-D was also formed, indicating that the $90 \%$ conversion, observed under the best conditions, was not due to incomplete deprotonation of the starting material.

Scheme 5. Conversion of propargyl xyloside 3a to allene 4a-D and propargyl 3a-D with $t$-BuOD as the proton source.

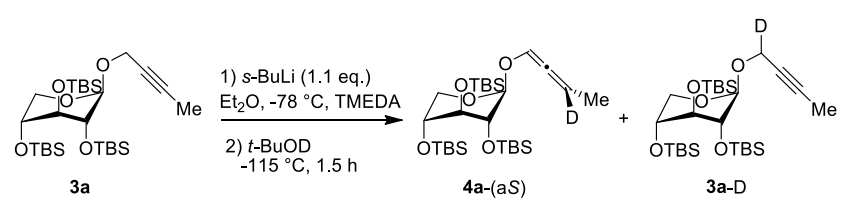

We were then interested in studying the influence of this metallotropic equilibrium on the regioselectivity previously obtained for the allenes $\mathbf{4 a}$. We tested several proton sources by varying the size and the nature of the alcohol (Table 3). Whereas primary alcohols, such as methanol or $n$-butanol still provided good d.r. values, significantly lower conversion was observed (entries 2 and 3). Surprisingly, isopropanol repeatedly furnished very low conversion (10\%) (entry 4). Quenching with phenol provided moderate conversion and d.r. (entry 5), whereas the more acidic 1,1,1,3,3,3hexafluoroisopropanol (HFIP) resulted in observations similar to $\mathrm{HCl}$, i.e. low conversion with no diastereoselectivity (entry 6).

Inspired by the work from Yoshida and co-workers, ${ }^{18}$ we also considered using chiral alcohols to have a double asymmetric induction in addition of the sugar moiety, expecting some "match" or "mismatch" effects in terms of stereoselectivity. With the chiral alcohol $(R)$ pantolactone very good conversion and moderate diastereoselectivity were observed (entry 7). With the $(S)$ isomer poor conversion of $40 \%$ and no diastereoselectivity were observed (entry 8). Finally, with $(R)$ - and $(S)$-mandelate, despite very good conversions, poor diastereoselectivities were obtained (entries 9 and 10).

The variation in regioselectivity obtained with the various proton sources indicates that the equilibrium between Li-propargyl / allenyl intermediates is rapid and the predominant formation of the allenes $4 \mathbf{a}$ mainly depends on the protonation step. ${ }^{16,19}$ 
Table 3. Study of the metallotropic equilibrium with various proton sources.

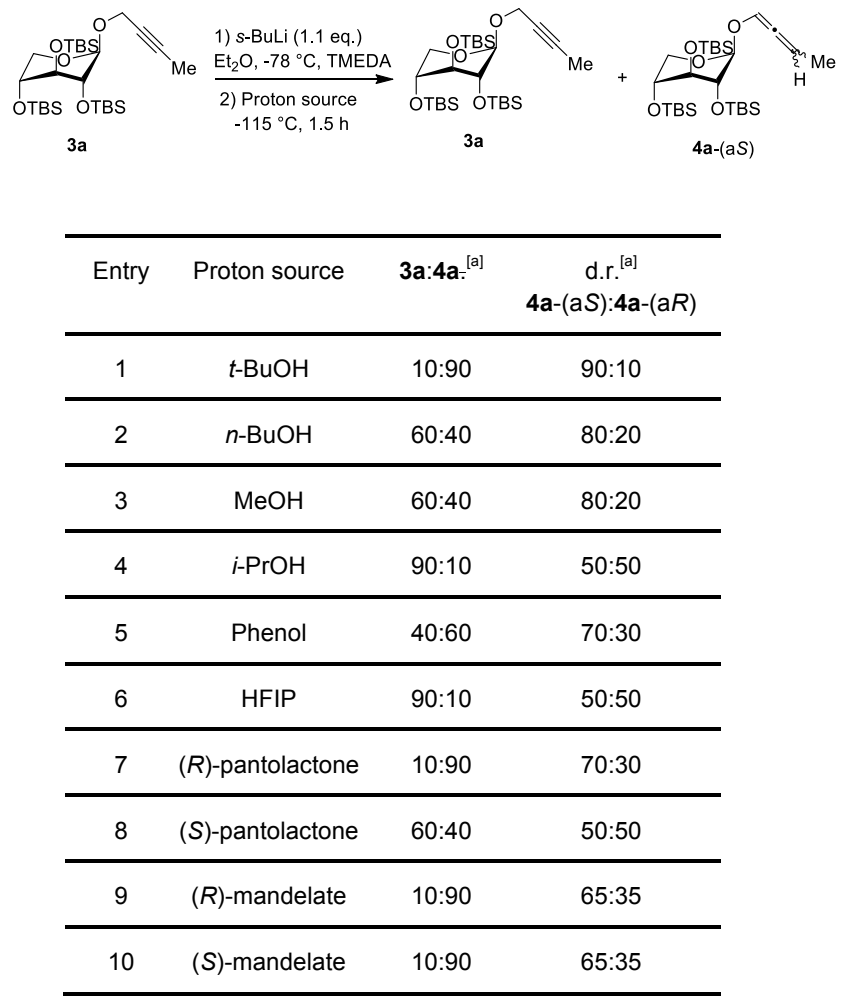

[a]: ${ }^{1} \mathrm{H}$ NMR shifts in ppm determined in $\mathrm{CDCl}_{3}$.

Influence of protecting groups on the sugar moiety on the diastereoselectivity. We next studied the impact of the alcohol protecting groups on the diastereoselectivity, using the OMe protected propargyl xyloside 5a. Under the optimised conditions determined for 4a (Table 2, entry 6), compound 5a gave only a 65:35 diastereomeric mixture of allenes $\mathbf{6 a}$ with high conversion (Scheme 6). This result clearly indicated that steric factors due to the bulky TBS groups are important in this transformation. Because the signals of the allenic protons $\mathrm{H}_{3}$ in the ${ }^{1} \mathrm{H}$ NMR spectra of the diastereoisomers of $4 \mathbf{a}$ and $6 \mathbf{a}$ deviated by less than $0.1 \mathrm{ppm}$ in all cases, the configuration of the major stereoisomer was assumed to be $(\mathrm{a} S)$. It should be noted that the $\mathrm{OMe}$ protected allene $\mathbf{6} \mathbf{a}$ is less stable over silica gel than the corresponding OTBS products, leading to low isolated yields.
Scheme 6. Conversion of propargyl xyloside 5a into allene $6 a$.
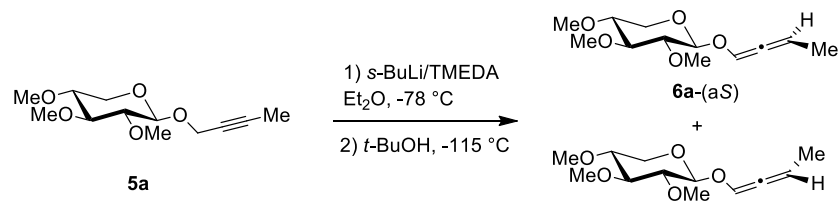

6a: $91 \%$ conv., (aS): $(a R)=65: 35$

6a-(aR)

Extension of the scope to the synthesis of allenes 4b-f with various substituents. With the optimised conditions in hand (Table 2, entry 6), we next extended this approach to other alkyl-substituted as well as silyl and aryl-substituted propargyl xylosides $\mathbf{3 b}$-f (Table 4).

Trialkylsilyl substitution on the sp-hybridized carbon atom of the propargyl alkyne group has previously been shown to significantly influence the reaction outcome for allene synthesis. ${ }^{10} \mathrm{We}$ therefore examined the substrate $\mathbf{3 b}$ having a TMS substituent. Low conversion to the allene $\mathbf{4 b}$ with moderate d.r. was observed (entry 2 ). Due to the small difference in polarity between $\mathbf{3 b}$ and $\mathbf{4 b}$ these products could not be separated by column chromatography. With the phenyl substituted starting compound 3c moderate conversion and d.r. values were obtained, even though these are the highest value to date in the literature (entry 3). Substitution of the aromatic nucleus by an electron-donating group (entry 4) brings a slight reduction in the conversion while the substitution by an electron-withdrawing group (entry 5) leads to total conversion to the allene with a diastereoisomeric ratio of 55:45. In agreement with a previous literature report, ${ }^{21}$ these arylsubstituted allenes showed significantly lower stability over time and over silica gel (or alumina), compared to their alkyl analogues, and therefore could not be isolated in a pure form. With the propargyl xyloside having a bulky $t$-Bu group $3 f$ (entry 6) full conversion to allene 4f was observed, however with a slightly lower d.r. compared to the methyl group. It was found that this compound was stable for purification over silica gel and a mixture of the two diastereomers could be obtained with a quantitative yield. 
Table 4. Scope of the synthesis of allenes $4 a-f$ from propargyl xylosides 3a-f.

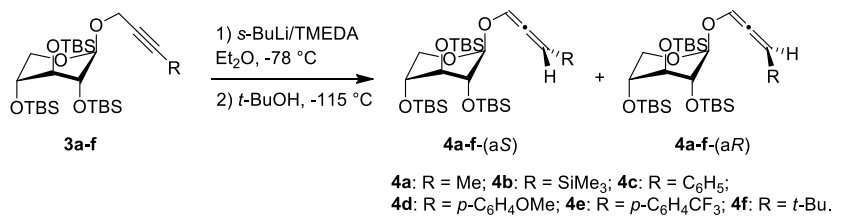

\begin{tabular}{|c|c|c|c|}
\hline Entry & $\mathrm{R}$ & $\begin{array}{c}\text { Conv. }(\%)^{[a]} \\
\text { (isolated yields) }\end{array}$ & $\begin{array}{c}\text { d.r. }^{[a]} \\
\text { 4-(aS):4- } \\
(\mathrm{a} R)^{[\mathrm{b}]}\end{array}$ \\
\hline 1 & $\operatorname{Me}(\mathbf{3 a})$ & $90(75 \%)$ & (4a) $93: 7$ \\
\hline 2 & TMS (3b) & $42(-)$ & (4b) $70: 30$ \\
\hline 3 & $\mathrm{C}_{6} \mathrm{H}_{5}(3 \mathrm{c})$ & $65(-)$ & (4c) $70: 30$ \\
\hline 4 & $p-\mathrm{C}_{6} \mathrm{H}_{4} \mathrm{OMe}(\mathbf{3 d})$ & $50(-)$ & (4d) $70: 30$ \\
\hline 5 & $p-\mathrm{C}_{6} \mathrm{H}_{4} \mathrm{CF}_{3}(\mathbf{3 e})$ & $100(-)$ & (4e) $55: 45$ \\
\hline 6 & $t-\mathrm{Bu}(\mathbf{3 f})$ & 100 (quant.) & (4f) $80: 20$ \\
\hline
\end{tabular}

[a]: d.r. were determined by ${ }^{1} \mathrm{H}$ NMR in $\mathrm{CDCl}_{3}$ from crude reaction mixtures; [b]: we assumed that the stereochemistry preferentially formed for all the allenes $\mathbf{4 b}$-f was $(a S)$, taking into account previous result obtained with $4 \mathrm{a}$ and previous works. ${ }^{4}$

Table 5 provides the values of the chemical shifts for the signals of the allenic protons $\mathrm{H}_{1^{\prime}}$ and $\mathrm{H}_{3^{\prime}}$ in solution in $\mathrm{CDCl}_{3}$ for the new allenes $\mathbf{4 a - f}$ and $\mathbf{6 a}$,b. Literature data on alkoxyallenes with aryl groups are scarce due to their poor stability. ${ }^{21,22}$ In the case of $\mathbf{4 c - 4 e}$, we have assigned the signals from the spectra of the crude reaction mixtures. These data are in agreement with those of the slightly more stable compound $\mathbf{6 b}$ with a $p$-F$\mathrm{C}_{6} \mathrm{H}_{4}$ group on the allene and OMe protecting groups, obtained under different conditions and fully characterized in solution by NMR. From these values, a strong influence on the chemical shifts of $\mathrm{H}_{1}{ }^{\prime}$ and $\mathrm{H}_{3}$ ' can be observed between alkyl/SiMe 3 groups (entries 1,2,6,7) and aryl groups (entries $3,4,5,8$ ). Only a weak electronic effect of the aryl groups on the chemical shift became evident.

DFT studies on the diastereoselective formation of allene 4a-(aS). The mechanism leading to the major diastereoisomer 4a-(aS) was next studied by DFT calculations. As the reaction was performed at $-110^{\circ} \mathrm{C}$, the OTBS groups were placed in equatorial position for the calculations, as this was found to be the major conformation at low temperature $\left(-70^{\circ} \mathrm{C}\right)$, according to our variable-temperature ${ }^{1} \mathrm{H}$ NMR studies (Table 1). In agreement with previous works, ${ }^{1 a, b}$ we propose a twostep mechanism for the allene formation. The first step would consist in the deprotonation of the propargyl xyloside 3a with the base, leading to four possible intermediates in equilibrium 3a-Li- $(S)$, 3a- $\mathrm{Li}-(R), \mathbf{4 a}-\mathrm{Li}-$ $(\mathrm{a} S)$ and $4 \mathbf{a}-\mathrm{Li}-(\mathrm{a} R)$ as revealed by DFT calculations (Scheme 7). ${ }^{23}$
Table 5. Chemical shifts observed by ${ }^{1} \mathrm{H}$ NMR for protons $\mathrm{H}_{1^{\prime}}$ et $\mathrm{H}_{3^{\prime}}$ of new allenes $4 \mathrm{a}-\mathrm{f}$ and $6 \mathrm{a}, \mathrm{b}$.

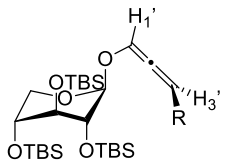

$4 a-$

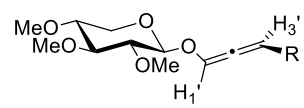

$6 a, b$

\begin{tabular}{|c|c|c|c|c|}
\hline Entry & Compound & $\mathrm{R}$ & $\delta \mathrm{H}_{1}{ }^{\left[{ }^{[a]}\right.}$ & $\delta \mathrm{H}_{3}{ }^{\left[{ }^{a]}\right]}$ \\
\hline 1 & $4 a$ & $\mathrm{Me}$ & $\begin{array}{l}6.47(\mathrm{aS}) \\
6.50(\mathrm{a} R)\end{array}$ & $\begin{array}{l}5.70(\mathrm{aS}) \\
5.80(\mathrm{a} R)\end{array}$ \\
\hline 2 & $4 \mathrm{~b}$ & $\mathrm{SiMe}_{3}$ & $\begin{array}{l}6.48(a S) \\
6.53(a R)\end{array}$ & $\begin{array}{l}5.83(\mathrm{a} S) \\
5.86(\mathrm{a} R)\end{array}$ \\
\hline 3 & $4 c$ & $\mathrm{Ph}$ & $6.94(\mathrm{a} S+\mathrm{a} R)$ & $\begin{array}{l}6.66(\mathrm{aS}) \\
6.76(\mathrm{a} R)\end{array}$ \\
\hline 4 & $4 d$ & $p-\mathrm{C}_{6} \mathrm{H}_{4} \mathrm{OMe}$ & $6.90(\mathrm{a} S+\mathrm{a} R)$ & $\begin{array}{l}6.62(\mathrm{aS}) \\
6.72(\mathrm{a} R)\end{array}$ \\
\hline 5 & $4 e$ & $p-\mathrm{C}_{6} \mathrm{H}_{4} \mathrm{CF}_{3}$ & $7.00(\mathrm{a} S+\mathrm{a} R)$ & $\begin{array}{l}6.67(\mathrm{a} S) \\
6.78(\mathrm{a} R)\end{array}$ \\
\hline 6 & $4 f$ & $t$-Bu & $\begin{array}{l}6.53(\mathrm{a} R) \\
6.57(\mathrm{aS})\end{array}$ & $\begin{array}{l}5.72(\mathrm{a} R) \\
5.80(\mathrm{a} S)\end{array}$ \\
\hline 7 & $6 a$ & $\mathrm{Me}$ & $6.55(\mathrm{a} S+\mathrm{a} R)$ & $\begin{array}{l}5.75(\mathrm{a} S) \\
5.83(\mathrm{a} R)\end{array}$ \\
\hline 8 & $6 b$ & $p-\mathrm{C}_{6} \mathrm{H}_{4} \mathrm{~F}$ & $7.01(\mathrm{a} R+\mathrm{a} S)$ & $\begin{array}{l}6.66(\mathrm{aS}) \\
6.75(\mathrm{a} R)\end{array}$ \\
\hline
\end{tabular}

[a]: ${ }^{1} \mathrm{H}$ NMR shifts in ppm determined in $\mathrm{CDCl}_{3}$.

Scheme 7. Deprotonation of 3a leading to four intermediates lithium species: $3 \mathrm{a}-\mathrm{Li}-(S), 3 \mathrm{a}-\mathrm{Li}-(R), 4 \mathrm{a}-$ $\mathrm{Li}-(\mathrm{a} S)$ and $4 \mathrm{a}-\mathrm{Li}-(\mathrm{a} R)$.

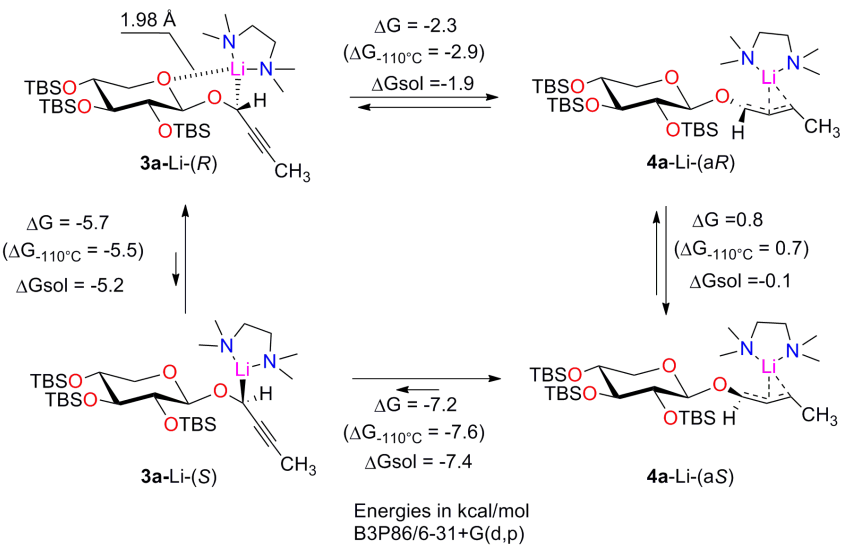

In contrast to the general description of lithiumallenyl species with the lithium bound to the terminal 
carbon atom, DFT calculations show that in $\mathbf{4 a - L i -}$ $(\mathrm{a} S) /(\mathrm{a} R)$ the lithium is $\eta^{3}$-coordinated to the allenyl moiety as indicated by the Li-C distances in the range of 2.04 to $2.56 \AA$ (Figure 2). ${ }^{10}$ Furthermore, an interaction between $\mathrm{Li}$ and the oxygen atom of the pyranosic cycle was observed for lithium propargyl complex 3a-Li- $(R)$, with a Li-O distance of $1.98 \AA$ (Figure 2). For 3a-Li-(S) such an interaction was not observed.

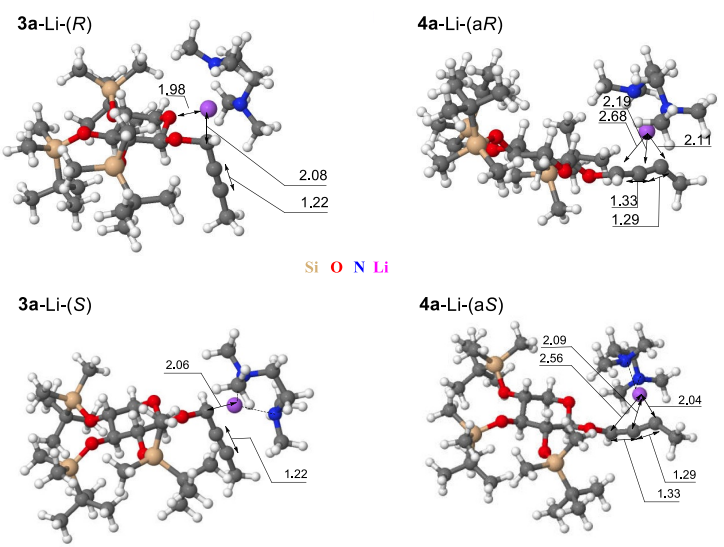

Figure 2. Calculated structures of 3a-Li- $(S)$, 3a- $\mathrm{Li}-(R)$, 4a-Li-(aS) and 4a-Li-(aR) at B3P86/6-31+G(d,p) level, distances in $\AA$.

Among the four isomers, the allenyllithium $4 \mathbf{a}-\mathrm{Li}-(\mathrm{a} S)$ is thermodynamically favoured and should lead to the major diastereoisomer 4a-(aS) upon protonation. Variation of temperature or taking into account the solvent did not significantly influence the calculated equilibrium. As described experimentally, the protecting groups and the alkyne substituents can lead to considerable variation in the reaction outcome. Therefore, we also calculated the four lithiated structures for the trimethylsilyl substrate $\mathbf{3 b}$ and the OMe protected sugar substrate 5a (see SI). Considerable changes in the $\Delta \mathrm{G}$ values for the different propargyl and allenyllithium species of the equilibrium could be observed, which might be responsible for the lower conversion and $d . r$. values observed with these substrates.

We then studied the second step of this mechanism, the protonation step of the lithium species, using $\mathrm{MeOH}$ as the protonation agent. ${ }^{24}$ We sought to obtain a stable structure, where a $\mathrm{MeOH}$ molecule would present an interaction with one of the different lithium species shown in Scheme 7. We studied these processes by scanning the potential energy surface corresponding to the approach of $\mathrm{MeOH}$ on the $\mathrm{C}_{1^{\prime}}$ atom or the $\mathrm{C}_{3^{\prime}}$ atom of the lithium species. First, we explored the protonation of $4 \mathbf{a}-\mathrm{Li}-(\mathrm{a} S)$, which is the thermodynamically favoured complex and should lead to the observed major allene 4a-(aS). In a first scan by shortening the distance $\mathrm{MeO}$ $\mathrm{H}---\mathrm{C}^{\prime}$, step by step of $0.1 \AA$, the $\mathrm{MeOH}$ molecule is positioned so as to allow interaction between the oxygen, which will transfer a proton, and the lithium ion. After the proton transfer, this generates a TMEDA-LiOMe species and the allene $4 a-(a S)$ in a $\mathrm{S}_{\mathrm{E}} 2$ mechanism without energy barrier (Scheme 8 and Figure 3a). The formation of the Li-OMe bond (distance O-Li $1.83 \AA$ A just before the proton transfer) seems to increase the effectiveness of this protonation step. This point became further evident when in another surface exploration, the $\mathrm{MeOH}$ was approached from the side opposite of the Li-TMEDA chelate (Figure 3b). In this case, a very high energy cost was observed as the methanolate is too far away from the Li-ion and therefore this approach seems an unfavorable protonation pathway.

Scheme 8. Possible $S_{\mathrm{E}} 2$ pathway for the protonation of 4a-Li-(aS).
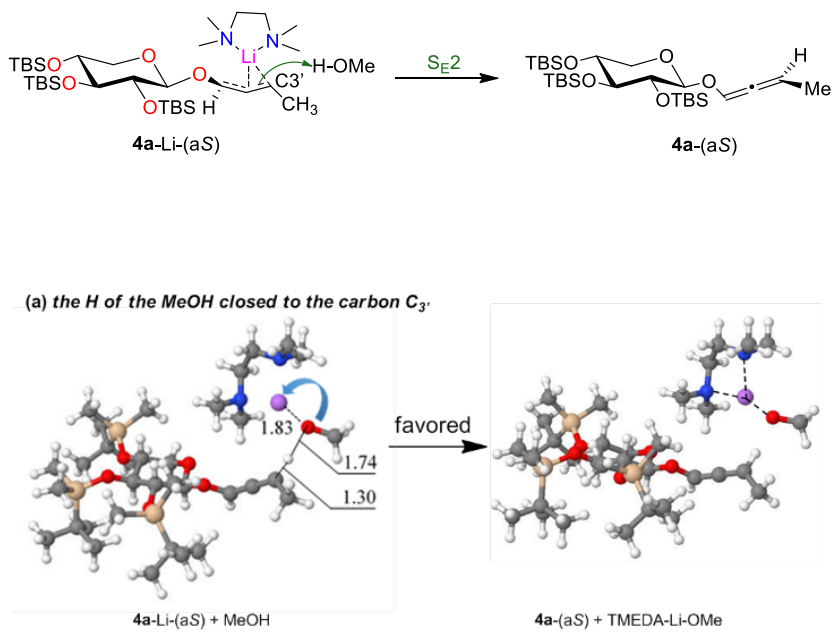

(b) the bringing of MeOH by the other side of the Li-TMEDA chelate

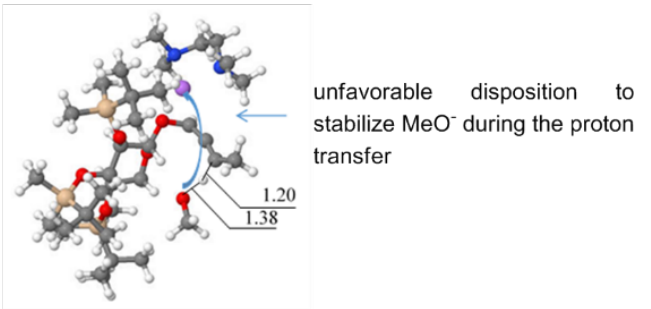

Figure 3. DFT Calculations: (a) favored and (b) unfavored protonation pathways of $\mathbf{4 a - L i -}(S)$.

For the formation of allenes, a protonation of the Lipropargyl-intermediate has also been proposed by Tius. ${ }^{4 a}$ From the propargylic structure $3 \mathbf{a}-\mathrm{Li}-(S)$, two protonation pathways were studied (Scheme 9): a) a protonation leading to the recovery of starting product 3a $\left(S_{E} 2\right)$, and b), a protonation leading to allene $4 \mathbf{a}$ $\left(\mathrm{S}_{\mathrm{E}} 2^{\prime}\right) .{ }^{1 \mathrm{a}, \mathrm{b}}$ These two pathways position the $\mathrm{MeOH}$ initially in the Li-TMEDA chelate environment. 
Scheme 9. Two possible pathways for the protonation of 3a-Li-(S): $S_{\mathrm{E}} 2$ and $S_{\mathrm{E}} 2$ '.

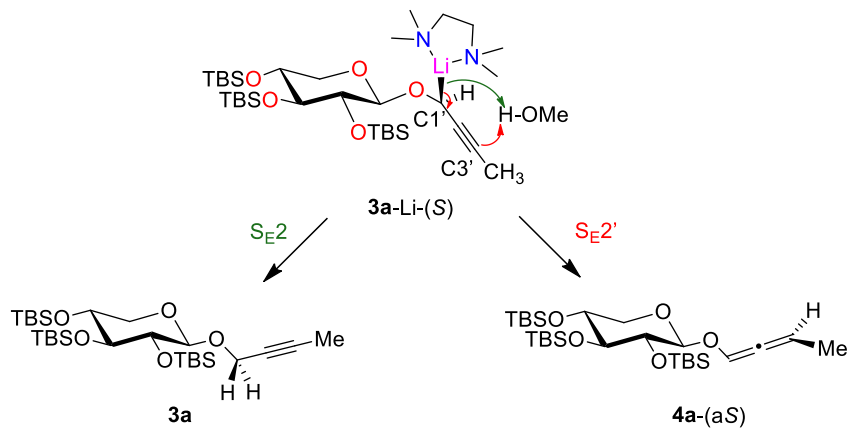

In a first surface exploration corresponding to pathway a), the distance $\mathrm{MeO}-\mathrm{H}---\mathrm{C}_{1^{\prime}}$ was shortened and the $\mathrm{MeOH}$ molecule was positioned so as to allow interaction between the oxygen, which will transfer a proton, and the lithium ion to generate after transfer, a TMEDA$\mathrm{Li}$-OMe species and the propargyl xyloside 3a (Figure 4a). This process is globally barrier-less and the driving force for this reaction seems again the formation of the Li-OMe bond (distance O-Li $1.85 \AA$ just before the proton transfer). In a second surface exploration (pathway b), we brought the $\mathrm{H}$ of $\mathrm{MeOH}$ closer to $\mathrm{C}_{3}$, to see if the allenic structure could be formed in this way (Figure 4b). And indeed, it is possible to access $4 a-(a S)$, the major diastereoisomer experimentally observed in agreement with the X-ray studies, in an almost barrierfree process judging by the observation of the evolution of energy during the shortening of the $\mathrm{MeO}-\mathrm{H}---\mathrm{C}_{3^{\prime}}$ distance. Once again, allowing interaction between the 0 that will transfer the proton and the $\mathrm{Li}$ (distance $\mathrm{O}-\mathrm{Li}$ of $1.83 \AA$ A) stabilizes the system. The situation became again very different, when in a third scan in analogy to the process shown in Figure 3b, the $\mathrm{MeOH}$ was brought closer to the opposite side of the Li-TMEDA chelate. As the methanolate formed during the proton transfer cannot be stabilized by the Li ion, too far away on the opposite side, the energy cost of this transfer, was found much higher (the evolution of energy is in adequacy, see Scheme S6 in SI), and therefore the formation of $4 \mathbf{a}-(\mathrm{a} R)$ is highly disadvantaged.

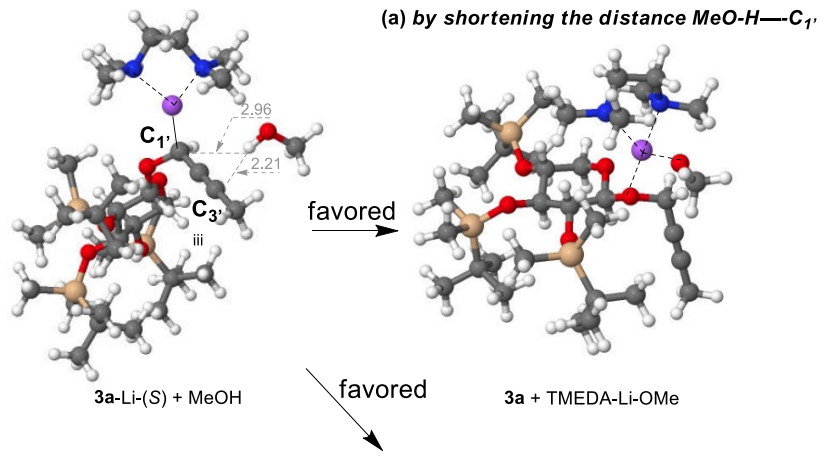

(b) by shortening the distance $\mathrm{MeO}-\mathrm{H}-\mathrm{C}_{3}$,

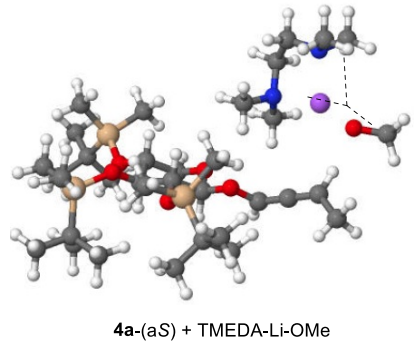

Figure 4. DFT Calculations: favored protonation pathways of 3a-Li- $(S)$.

\section{Conclusion}

In conclusion, we have reported an in-depth study on the diastereoselective synthesis of new 1,3disubstituted alkoxyallenes using a xyloside as chiral auxiliary. This procedure could be applied to a variety of substituted propargyl xylosides, including alkyl, silyl and aryl groups. Depending on the steric bulk and the electronic influence good to excellent yields and moderate to high d.r. values were observed. NMR spectroscopy, DFT calculations and X-ray structure analysis provided insights on the structure of the major diastereoisomer $\mathbf{4 a}-(\mathrm{a} S)$ as well as the underlying mechanism of its formation. At this stage of the study, it is not possible to definitively discriminate between the two mechanisms $\mathrm{S}_{\mathrm{E}} 2$ and $\mathrm{S}_{\mathrm{E}} 2$ ' for the protonation step. The large size of the system and the protonation almost without energy barrier did not allow to obtain transition states of the reaction and thus data concerning the kinetics of the reaction. In addition, other parameters, such as the aggregation of the alcohol in ether at $-115{ }^{\circ} \mathrm{C}$ of the intermediate lithium complexes, are not known. Nevertheless, this study brings a certain number of new general elements for these isomerization processes with alkoxy derivatives. The existence of the metallotropic equilibrium has been demonstrated by deuteration reactions, variable temperature reactions and by DFT studies. The different regioselectivities obtained depending on the proton source show that the interconversion between $\mathrm{Li}$ propargyl/allenyl intermediates during the metallo- 
tropic equilibrium is rapid and has no real influence on the regio- and the diastereo-selective outcome of the reaction. The predominant formation of the allenes $\mathbf{4 a}$ mainly depends on the protonation step. The DFT studies have also evidenced structural aspects on the lithium species in particular about the chelation of the lithium atom i) in the Li-propargyl (P), to the cyclic oxygen of the sugar, ii) in the Li-allenyl (A), over the whole allenyl fragment. In addition, these theoretical studies have also shown that during the protonation step, the approach of the proton source must be done on the same side as the chelate Li-TMEDA and the driving force for this reaction seems the formation of a LiOMeTMEDA complex. Since we now dispose of a new family of allenes, their use as precursors in the diastereoselective synthesis of more complex molecules such as new heterocycles will be investigated.2e,5b

\section{Experimental part}

\section{General Information}

All manipulations were performed under strict exclusion of air or moisture on a vacuum line using Schlenk techniques or in dry boxes under purified argon atmosphere. All solvents (THF, diethyl ether) were dispensed by a solvent dispenser (PureSolvTM by Innovative Technology). But-2-yn-1-ol was commercially available and used as received. 1,2,3,4-tetra- $O$-acetyl- $\beta$-Dxylopyranose 7,11b 3-(4-fluorophenyl)prop-2-yn-1-ol25 and 4,4-dimethylpent-2-yn-1-ol ${ }^{26}$ were synthesized as previously described in the literature. NMR measurements were obtained using a Bruker Avance I spectrometer equipped with a QNP probe $(250 \mathrm{MHz}$ for the $\left.{ }^{1} \mathrm{H}\right)$, a Bruker Avance III spectrometer equipped with a $\mathrm{BBFO}+$ probe $\left(500 \mathrm{MHz}\right.$ for ${ }^{1} \mathrm{H}, 126 \mathrm{MHz}$ for ${ }^{13} \mathrm{C}$ and 471 $\mathrm{MHz}$ for ${ }^{19} \mathrm{~F}$ ) or a Bruker Avance III spectrometer equipped with a CPTCI Cryosonde $\left(600 \mathrm{MHz}\right.$ for ${ }^{1} \mathrm{H}$ and $151 \mathrm{MHz}$ for ${ }^{13} \mathrm{C}$ ). The spectra were recorded at $298 \mathrm{~K}$ in $\mathrm{CDCl}_{3}$, dried over molecular sieves unless mentioned otherwise. Chemical shifts are expressed in parts per million (ppm) and pattern abbreviations are s for singlet, $d$ for doublet, dd for doublet of doublet, $t$ for triplet, $\mathrm{q}$ for quartet, quint for quintuplet, sext for sextuplet and $\mathrm{m}$ for multiplet. High resolution ESI-MS spectra were recorded on a hybrid tandem quadrupole/time-of-flight (Q-TOF) instrument, equipped with a pneumatically assisted electrospray (Z-spray) ion source (Micromass, Manchester, UK) operated in positive mode. High resolution EI-MS spectra were obtained on a GCT-TOF mass spectrometer (Micromass, Manchester, UK) with EI source. Crystallographic data was collected on a Bruker D8 Venture diffractometer and on the MX2 beamline at the Australian Synchrotron facility. ${ }^{27}$ The melting points were measured in capillary tubes with an SMP3 melting point device from Stuart Equipment. Optical rotations were measured on a Perkin Elmer 341 polarimeter. Infrared spectra were obtained from neat compounds, on a Nicolet 'Magna 550' spectrometer using an ATR (Attenuated Total Reflection) module. Elemental analyses were performed on a Thermo Electron Flash EA. All reagents were purchased from commercial sources and were used as received, unless noted otherwise.

Synthesis of 2-(prop-2-yn-1-yl)-2,3,4-tri-O-tbutyldimethylsilyl- $\beta$-D-xylopyranoside 2 . To a solution of the unprotected xyloside $\mathbf{1}(0.61 \mathrm{~g}, 8.56 \mathrm{mmol})$ in DMF $(10 \mathrm{~mL})$ were added imidazole $(2.9 \mathrm{~g}, 42.8 \mathrm{mmol})$, TBSCl (5.18 g, $34.24 \mathrm{mmol}$ ) and DMAP (45 mg, 0.17 $\mathrm{mmol} \mathrm{ca}$ ) and the mixture was heated at $80{ }^{\circ} \mathrm{C}$ with an oil bath for 6 days. Then, the resulting mixture was diluted with water, extracted with $\mathrm{CH}_{2} \mathrm{Cl}_{2}$, washed with $10 \% \mathrm{NaHCO}_{3}$ and brine. The combined organic extracts were dried over $\mathrm{MgSO}_{4}$, filtered and concentrated under reduced pressure. The crude residue was purified by flash column chromatography over silica gel $(10 \%$ EtOAc in hexanes) to afford the TBS-protected xyloside 2 as a colorless solid in $91 \%$ yield $\left(4.15\right.$ g). ${ }^{1} \mathrm{H}$ NMR $\left(500 \mathrm{MHz}, \mathrm{CDCl}_{3}\right) \delta 4.75\left(\mathrm{~d}, J=3.3 \mathrm{~Hz}, 1 \mathrm{H}, \mathrm{H}_{1}\right), 4.25(\mathrm{dd}$, $J=15.7,2.4 \mathrm{~Hz}, 1 \mathrm{H}, \mathrm{H}_{1^{\prime}}$ ) 4.21 (dd, $J=15.7,2.4 \mathrm{~Hz}, 1 \mathrm{H}$, $\left.\mathrm{H}_{1^{\prime}}\right), 4.02\left(\mathrm{dd}, J=11.6,2.9 \mathrm{~Hz}, 1 \mathrm{H}, \mathrm{H}_{5}\right), 3.61(\mathrm{t}, J=3.9 \mathrm{~Hz}$, $\left.1 \mathrm{H}, \mathrm{H}_{4}\right), 3.56\left(\mathrm{~m}, 1 \mathrm{H}, \mathrm{H}_{3}\right), 3.52\left(\mathrm{t}, J=3.3 \mathrm{~Hz}, 1 \mathrm{H}, \mathrm{H}_{2}\right), 3.40$ (dd, $\left.J=11.6,3.9 \mathrm{~Hz}, 1 \mathrm{H}, \mathrm{H}_{5}\right), 2.37\left(\mathrm{t}, J=2.4 \mathrm{~Hz}, 1 \mathrm{H}, \mathrm{H}_{3^{\prime}}\right.$ ), 0.90-0.74 (27H, CH $\left.\mathrm{CH}_{3(\mathrm{Sit}-\mathrm{Bu})}\right), 0.12-0.06\left(18 \mathrm{H}, \mathrm{CH}_{3(\mathrm{SiMe})}\right)$. ${ }^{13} \mathrm{C}\left\{{ }^{1} \mathrm{H}\right\}$ NMR $\left(126 \mathrm{MHz}, \mathrm{CDCl}_{3}\right) \delta 99.7\left(\mathrm{C}_{1}\right), 79.5\left(\mathrm{C}_{2^{\prime}}\right)$, $74.3\left(\mathrm{C}_{3^{\prime}}\right), 74.1\left(\mathrm{C}_{3}\right), 73.3\left(\mathrm{C}_{2}\right), 70.5\left(\mathrm{C}_{4}\right), 63.2\left(\mathrm{C}_{5}\right), 54.4$ $\left(\mathrm{C}_{1}\right), 26.3,26.2,26.1\left(\mathrm{CH}_{3(\mathrm{Sit}-\mathrm{Bu})}\right), 18.4,18.0\left(\mathrm{C}_{\mathrm{q}(\mathrm{Sit}-\mathrm{Bu})}\right)$, 3.8, -3.9, -4.0, -4.1, -4.6 ( $\left.\mathrm{CH}_{3(\mathrm{SiMe})}\right)$. HRMS (EI) m/z: $[\mathrm{M}+\mathrm{Na}]^{+}$Calcd for $\mathrm{C}_{26} \mathrm{H}_{54} \mathrm{O}_{5} \mathrm{NaSi}_{3}$ 553.3177; Found 553.3190. $[\alpha]^{20}{ }_{\mathrm{D}}=-12.5\left(\mathrm{c} 1.1, \mathrm{CHCl}_{3}\right.$ ). m.p. $3{ }^{\circ} \mathrm{C}$. IR (neat, $\mathrm{cm}^{-1}$ ) 2928, 2855, 1471, 1463, 1389, 1256, 1251, 1091, 1011, 831, 673.

\section{General procedure for the alkylation/silylation reactions with 2}

To a solution of $\mathbf{2}$ in dry THF, was slowly added $n$-BuLi (1.1 eq.) at $-78{ }^{\circ} \mathrm{C}$. After $1 \mathrm{~h}$, the corresponding $\mathrm{CH}_{3} \mathrm{I}$ or TMSCl (2 eq.) was added dropwise. The mixture was stirred for $1 \mathrm{~h}$ whilst being allowed to warm to room temperature. A saturated aqueous $\mathrm{NaHCO}_{3}$ solution was added, and the two phases were separated. The aqueous phase was then extracted with $\mathrm{Et}_{2} \mathrm{O}$. The combined organic phases were dried over $\mathrm{MgSO}_{4}$, filtered and the solvents were evaporated. The crude reaction mixture was purified by a flash column chromatography over silica gel (eluent: PE/EtOAc 9:1) to afford the substituted alkyne.

Synthesis of 2-(but-2-yn-1-yl)-2,3,4-tri-O-tbutyldimethylsilyl- $\beta$ - $D$-xylopyranoside $3 \mathbf{a}$. According to the general procedure, $2(1.47 \mathrm{~g}, 2.79 \mathrm{mmol}), n$ butyllithium $(1.34 \mathrm{~mL}, 3.32 \mathrm{mmol})$ and iodomethane (0.6 $\mathrm{mL}, 5.58 \mathrm{mmol})$ were reacted in THF $(15 \mathrm{~mL})$ to 
afford product 3a as a colorless oil in $94 \%$ yield $(1.46 \mathrm{~g}$, $2.68 \mathrm{mmol}$ ). ${ }^{1} \mathrm{H}$ NMR (500 MHz, $\left.\mathrm{CDCl}_{3}\right) \delta 4.75(\mathrm{~d}, J=3.4$ $\mathrm{Hz}, 1 \mathrm{H}, \mathrm{H}_{1}$ ), 4.26 (d, $J=15.3 \mathrm{~Hz}, 1 \mathrm{H}, \mathrm{H}_{1^{\prime}}$ ), 4.20 (d, $J=15.3$ $\left.\mathrm{Hz}, 1 \mathrm{H}, \mathrm{H}_{1^{\prime}}\right), 4.00\left(\mathrm{dd}, J=11.6,3.0 \mathrm{~Hz}, 1 \mathrm{H}, \mathrm{H}_{5}\right), 3.60(\mathrm{~m}$, $\left.1 \mathrm{H}, \mathrm{H}_{3}\right), 3.55\left(\mathrm{~m}, 1 \mathrm{H}, \mathrm{H}_{4}\right), 3.49\left(\mathrm{t}, J=3.4 \mathrm{~Hz}, 1 \mathrm{H}, \mathrm{H}_{2}\right), 3.37$ (dd, $\left.J=11.6,4.0 \mathrm{~Hz}, 1 \mathrm{H}, \mathrm{H}_{5}\right), 1.82\left(\mathrm{t}, J=2.3 \mathrm{~Hz}, 3 \mathrm{H}, \mathrm{CH}_{3}\right.$ ), 0.95-0.84 (27H, CH $3(\mathrm{Sit}-\mathrm{Bu})), 0.12-0.05\left(18 \mathrm{H}, \mathrm{CH}_{3(\mathrm{SiMe})}\right)$. ${ }^{13} \mathrm{C}\left\{{ }^{1} \mathrm{H}\right\}$ NMR $\left(151 \mathrm{MHz}, \mathrm{CDCl}_{3}\right) \delta 99.3\left(\mathrm{C}_{1}\right), 82.4\left(\mathrm{C}_{2^{\prime}}\right)$, $74.9\left(\mathrm{C}_{3^{\prime}}\right), 74.2\left(\mathrm{C}_{3}\right), 73.5\left(\mathrm{C}_{2}\right), 70.6\left(\mathrm{C}_{4}\right), 63.3\left(\mathrm{C}_{5}\right), 55.0$ $\left(\mathrm{C}_{1}\right), 26.3,26.2,26.1\left(\mathrm{CH}_{3(\mathrm{Sit}-\mathrm{Bu})}\right), 18.5,18.4,18.0\left(\mathrm{C}_{\mathrm{q}(\text { Sit- }}\right.$ $\mathrm{Bu})$ ), $3.7\left(\mathrm{CH}_{3}\right),-3.8,-3.9,-4.0,-4.1,-4.6\left(\mathrm{CH}_{3(\mathrm{SiMe})}\right)$. HRMS (EI) $\mathrm{m} / \mathrm{z}:[\mathrm{M}+\mathrm{Na}]^{+}$Calcd for $\mathrm{C}_{27} \mathrm{H}_{56} \mathrm{O}_{5} \mathrm{NaSi}_{3}$ 567.3333; Found 567.3340. $[\alpha]^{20} \mathrm{D}=-27\left(c\right.$ 0.55, $\left.\mathrm{CHCl}_{3}\right)$. IR (neat, $\left.\mathrm{cm}^{-1}\right)$ 2928, 2894, 1472, 1463, 1389, 1256, 1255, 1096, $1011,939,836,776$.

Synthesis of the 2-(3-(trimethylsilyl)prop-2-yn-1-yl)2,3,4-tri-O-t-butyldimethylsilyl- $\beta$-D-xylopyranoside $\mathbf{3 b}$. According to the general procedure, 2 (175 mg, 0.33 mmol), $n$-butyllithium ( $0.19 \mathrm{~mL}, 0.36 \mathrm{mmol})$ and TMSCl $(0.05 \mathrm{~mL}, 0.36 \mathrm{mmol})$, were reacted in THF (1 $\mathrm{mL})$ to afford product $\mathbf{3 b}$ as a colorless oil in quantitative yield (199 mg, $0.33 \mathrm{mmol}$ ). ${ }^{1} \mathrm{H}$ NMR (500 MHz, $\left.\mathrm{CDCl}_{3}\right) \delta 4.74$ $\left(\mathrm{d}, J=3.0 \mathrm{~Hz}, 1 \mathrm{H}, \mathrm{H}_{1}\right), 4.24\left(\mathrm{~d}, J=15.3 \mathrm{~Hz}, 1 \mathrm{H}, \mathrm{H}_{1^{\prime}}\right), 4.19$ (d, $J=15.3 \mathrm{~Hz}, 1 \mathrm{H}, \mathrm{H}_{1}$ ) , 3.99 (dd, $J=11.4,2.8 \mathrm{~Hz}, 1 \mathrm{H}, \mathrm{H}_{5}$ ), $3.60\left(\mathrm{t}, J=3.9 \mathrm{~Hz}, 1 \mathrm{H}, \mathrm{H}_{3}\right), 3.56-3.52\left(\mathrm{~m}, 1 \mathrm{H}, \mathrm{H}_{4}\right), 3.50(\mathrm{t}$, $\left.J=3.3 \mathrm{~Hz}, 1 \mathrm{H}, \mathrm{H}_{2}\right), 3.37\left(\mathrm{dd}, J=11.4,3.3 \mathrm{~Hz}, 1 \mathrm{H}, \mathrm{H}_{5}\right.$ ), 0.92-0.86 (27H, CH $\left.\mathrm{CH}_{3(\mathrm{Sit}-\mathrm{Bu})}\right), 0.15$ (s, 9H, $\mathrm{CH}_{3 \text { (TMS) }}$ ), 0.11-

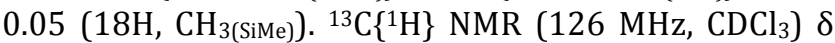
$101.4\left(\mathrm{C}_{2^{\prime}}\right), 99.3\left(\mathrm{C}_{1}\right), 91.1\left(\mathrm{C}_{3^{\prime}}\right), 73.7\left(\mathrm{C}_{3}\right), 73.1\left(\mathrm{C}_{2}\right), 70.4$ $\left(\mathrm{C}_{4}\right), 62.8\left(\mathrm{C}_{5}\right), 54.9\left(\mathrm{C}_{1}\right), 26.3,26.2,26.0\left(\mathrm{CH}_{3(\mathrm{Sit}-\mathrm{Bu})}\right)$, 18.5, 18.4, $18.0\left(\mathrm{C}_{\mathrm{q}(\mathrm{Sit}-\mathrm{Bu})}\right), 0.0\left(\mathrm{CH}_{3(\mathrm{TMS})}\right),-3.8,-3.9,-4.0$, 4.1, $-4.6\left(\mathrm{CH}_{3(\mathrm{SiMe})}\right)$. HRMS (EI) m/z: $[\mathrm{M}+\mathrm{Na}]^{+}$Calcd for $\mathrm{C}_{29} \mathrm{H}_{62} \mathrm{O}_{5} \mathrm{NaSi}_{4}$ 625.3572; Found 625.3580. $[\alpha]^{20} \mathrm{D}=-31$ (c $0.64, \mathrm{CHCl}_{3}$ ). IR (neat, $\mathrm{cm}^{-1}$ ) 2953, 2928,2895, 1732, $1472,1462,1388,1360,1250,1094,1011,938,832$, 773.

\section{General procedure for the Sonagashira coupling reactions with 3}

A dry Schlenk tube under argon atmosphere was charged with $\mathrm{Pd}\left(\mathrm{PPh}_{3}\right)_{4}$ (0.005 eq.) and $\mathrm{CuI}$ (0.01 eq.), 2 (1 eq.) and iodobenzene (1 eq.) were added followed by a mixture of THF/Et $3 \mathrm{~N}$ (1:1). After $24 \mathrm{~h}$ heating at $55^{\circ} \mathrm{C}$ with an oil bath, the reaction mixture was hydrolyzed with an aqueous solution of $\mathrm{NH}_{4} \mathrm{Cl}$ and extracted with diethyl ether. The organic phase was washed with a saturated $\mathrm{NaCl}$ solution, dried over $\mathrm{MgSO}_{4}$ and concentrated under reduced pressure. The crude reaction mixture was purified by a flash column chromatography over silica gel (eluent: PE/EtOAc 9:1) to afford the substituted alkyne.

Synthesis of 2-(3-phenylprop-2-yn-1-yl)-2,3,4-tri-O-tbutyldimethylsilyl- $\beta$-D-xylopyranoside 3c. According to the general procedure, 2 (210 $\mathrm{mg}, 0.39 \mathrm{mmol}), \mathrm{Pd}$ $\left(\mathrm{PPh}_{3}\right)_{4}(5 \mathrm{mg}), \mathrm{CuI}(6 \mathrm{mg})$ and iodobenzene $(0.05 \mathrm{~mL}$, $0.44 \mathrm{mmol})$ were reacted in a mixture of THF $(0.5 \mathrm{~mL})$ and $\mathrm{Et}_{3} \mathrm{~N}(2 \mathrm{~mL})$ to afford product $3 \mathrm{c}$ as a colorless oil in quantitative yield (223 mg, $0.37 \mathrm{mmol}) .{ }^{1} \mathrm{H}$ NMR (500 $\left.\mathrm{MHz} \mathrm{CDCl}_{3}\right) \delta 7.41\left(\mathrm{~m}, 2 \mathrm{H}, \mathrm{H}_{\mathrm{Ar}}\right), 7.30\left(\mathrm{~m}, 2 \mathrm{H}, \mathrm{H}_{\mathrm{Ar}}\right), 4.83$ $\left(\mathrm{d}, J=3.4 \mathrm{~Hz}, 1 \mathrm{H}, \mathrm{H}_{1}\right), 4.48\left(\mathrm{~d}, J=15.3 \mathrm{~Hz}, 1 \mathrm{H}, \mathrm{H}_{1^{\prime}}\right), 4.43$ $\left(\mathrm{d}, J=15.3 \mathrm{~Hz}, 1 \mathrm{H}, \mathrm{H}_{1^{\prime}}\right), 4.05\left(\mathrm{dd}, J=11.5,3.0 \mathrm{~Hz}, 1 \mathrm{H}, \mathrm{H}_{5}\right.$ ), $3.62\left(\mathrm{~m}, 1 \mathrm{H}, \mathrm{H}_{3}\right), 3.57\left(\mathrm{~m}, 1 \mathrm{H}, \mathrm{H}_{4}\right), 3.54(\mathrm{t}, J=3.4 \mathrm{~Hz}, 1 \mathrm{H}$, $\mathrm{H}_{2}$ ), 3.41 (dd, $\left.J=11.5,4.0 \mathrm{~Hz}, 1 \mathrm{H}, \mathrm{H}_{5}\right), 0.90\left(27 \mathrm{H}, \mathrm{CH}_{3(\mathrm{Sit}-}\right.$ $\mathrm{Bu})$ ), 0.13-0.03 (18H, $\left.\mathrm{CH}_{3(\mathrm{SiMe})}\right) .{ }^{13} \mathrm{C}\left\{{ }^{1} \mathrm{H}\right\}$ NMR $(126 \mathrm{MHz}$, $\left.\mathrm{CDCl}_{3}\right) \delta 131.8\left(\mathrm{C}_{\mathrm{Ar}}\right), 128.4\left(\mathrm{C}_{\mathrm{Ar}}\right), 128.3\left(\mathrm{C}_{\mathrm{Ar}}\right), 99.6\left(\mathrm{C}_{1}\right)$, $86.2\left(\mathrm{C}_{2^{\prime}}\right), 85.0\left(\mathrm{C}_{3^{\prime}}\right), 74.1\left(\mathrm{C}_{3}\right), 73.4\left(\mathrm{C}_{2}\right), 70.6\left(\mathrm{C}_{4}\right), 63.3$ $\left(\mathrm{C}_{5}\right), 55.1\left(\mathrm{C}_{1}\right), 26.3,26.2,26.1\left(\mathrm{CH}_{3(\mathrm{Sit}-\mathrm{Bu})}\right), 18.5,18.0$ $\left(\mathrm{C}_{\mathrm{q}(\mathrm{Sit}-\mathrm{Bu})}\right),-3.7,-3.9,-4.0,-4.6\left(\mathrm{CH}_{3(\mathrm{SiMe})}\right)$. HRMS (EI) m/z: $[\mathrm{M}+\mathrm{Na}]^{+}$Calcd for $\mathrm{C}_{32} \mathrm{H}_{58} \mathrm{O}_{5} \mathrm{NaSi}_{3}$ 629.3490; Found 629.3488. $[\alpha]^{20}{ }_{\mathrm{D}}=-30\left(c\right.$ 0.59, $\mathrm{CHCl}_{3}$ ). IR (neat, $\mathrm{cm}^{-1}$ ) 2928, 2856, 1748, 1471, 1361, 1251, 1043, 1078, 831.

Synthesis of 2-(3-(4-methoxyphenyl)prop-2-yn-1-yl)2,3,4-tri-O-t-butyldimethylsilyl- $\beta$-D-xylopyranoside $\mathbf{3 d}$. According to the general procedure, $2(370 \mathrm{mg}, 0.69$ $\mathrm{mmol}), \mathrm{Pd}\left(\mathrm{PPh}_{3}\right)_{4}(5 \mathrm{mg}), \mathrm{CuI}(6 \mathrm{mg})$ and 1-iodo-4methoxybenzene $(180 \mathrm{mg}, 0.76 \mathrm{mmol})$ were reacted in a mixture of THF $(1 \mathrm{~mL})$ and $\mathrm{Et}_{3} \mathrm{~N}(3.5 \mathrm{~mL})$ to afford product $3 \mathbf{d}$ as a colorless oil in $93 \%$ yield ( $409 \mathrm{mg}, 0.64$ mmol). ${ }^{1} \mathrm{H}$ NMR $\left(500 \mathrm{MHz}, \mathrm{CDCl}_{3}\right) \delta 7.35(\mathrm{~d}, J=8.4 \mathrm{~Hz}$, $\left.2 \mathrm{H}, \mathrm{H}_{\mathrm{Ar}}\right), 6.82\left(\mathrm{~d}, J=8.4 \mathrm{~Hz}, 2 \mathrm{H}, \mathrm{H}_{\mathrm{Ar}}\right), 4.82(\mathrm{~d}, J=3.2 \mathrm{~Hz}$, $\left.1 \mathrm{H}, \mathrm{H}_{1}\right), 4.46\left(\mathrm{~d}, J=15.3 \mathrm{~Hz}, 1 \mathrm{H}, \mathrm{H}_{1^{\prime}}\right), 4.41(\mathrm{~d}, J=15.3 \mathrm{~Hz}$, $\left.1 \mathrm{H}, \mathrm{H}_{1^{\prime}}\right), 4.04\left(\mathrm{dd}, J=11.6,2.7 \mathrm{~Hz}, 1 \mathrm{H}, \mathrm{H}_{5}\right) .3 .81(\mathrm{~s}, 3 \mathrm{H}$, $\left.\mathrm{OCH}_{3}\right), 3.61\left(\mathrm{~m}, 1 \mathrm{H}, \mathrm{H}_{3}\right), 3.57\left(\mathrm{~m}, 1 \mathrm{H}, \mathrm{H}_{4}\right), 3.53(\mathrm{t}, J=3.5$ $\left.\mathrm{Hz}, 1 \mathrm{H}, \mathrm{H}_{2}\right), 3.40$ (dd, $\left.J=11.6,3.9 \mathrm{~Hz}, 1 \mathrm{H}, \mathrm{H}_{5}\right), 0.90(27 \mathrm{H}$,

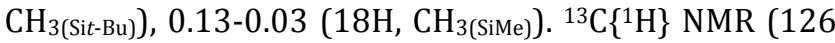
$\left.\mathrm{MHz}, \mathrm{CDCl}_{3}\right) \delta 159.7\left(\mathrm{C}_{\mathrm{Ar}}\right), 133.3\left(\mathrm{C}_{\mathrm{Ar}}\right), 114.0\left(\mathrm{C}_{\mathrm{Ar}}\right), 99.5$ $\left(\mathrm{C}_{1}\right), 86.1\left(\mathrm{C}_{2^{\prime}}\right), 83.5\left(\mathrm{C}_{3^{\prime}}\right), 74.1\left(\mathrm{C}_{3}\right), 73.4\left(\mathrm{C}_{2}\right), 70.6\left(\mathrm{C}_{4}\right)$, $63.3\left(\mathrm{C}_{5}\right), 55.4\left(\mathrm{C}_{1^{\prime}}\right), 55.2\left(\mathrm{OCH}_{3}\right), 26.3,26.2,26.1\left(\mathrm{CH}_{3}(\right.$ Sit$\mathrm{Bu})$, 18.5, $18.4\left(\mathrm{C}_{\mathrm{q}(\mathrm{Sit}-\mathrm{Bu})}\right),-3.8,-3.9,-4.0,-4.6\left(\mathrm{CH}_{3(\mathrm{SiMe})}\right)$. HRMS (EI) m/z: $[\mathrm{M}+\mathrm{Na}]^{+}$Calcd for $\mathrm{C}_{33} \mathrm{H}_{60} \mathrm{O}_{6} \mathrm{NaSi}_{3}$ 659.3595; Found 659.3599. $[\alpha]^{20} \mathrm{D}=-19$ (c 0.263, $\mathrm{CHCl}_{3}$ ). IR (neat, $\mathrm{cm}^{-1}$ ) 2929, 2895, 2857, 1509, 1404, 1388, 1322, 1250, 1079, 774.

Synthesis of 2-(3-(4-(trifluoromethyl)phenyl)prop-2-yn-1yl)-2,3,4-tri-O-t-butyldimethylsilyl- $\beta$-D-xylopyranoside

3e. According to the general procedure, 2 (370 mg,0.69 $\mathrm{mmol}), \mathrm{Pd}\left(\mathrm{PPh}_{3}\right)_{4}(5 \mathrm{mg}), \mathrm{CuI}(6 \mathrm{mg})$ and 1-iodo-4trifluoromethylbenzene $(0.12 \mathrm{~mL}, 0.76 \mathrm{mmol})$ were reacted in a mixture of THF $(1 \mathrm{~mL})$ and $\mathrm{Et}_{3} \mathrm{~N}(3.5 \mathrm{~mL})$ to afford product $3 \mathbf{e}$ as a colorless oil in $98 \%$ yield (459 $\mathrm{mg}, 0.68 \mathrm{mmol}) .{ }^{1} \mathrm{H}$ NMR $\left(500 \mathrm{MHz}, \mathrm{CDCl}_{3}\right) \delta 7.56(\mathrm{~d}, J=$ $\left.8.1 \mathrm{~Hz}, 2 \mathrm{H}, \mathrm{H}_{\mathrm{Ar}}\right), 7.50\left(\mathrm{~d}, J=8.1 \mathrm{~Hz}, 2 \mathrm{H}, \mathrm{H}_{\mathrm{Ar}}\right), 4.82(\mathrm{~d}, J=$ $\left.3.1 \mathrm{~Hz}, 1 \mathrm{H}, \mathrm{H}_{1}\right), 4.49\left(\mathrm{~d}, J=15.3 \mathrm{~Hz}, 1 \mathrm{H}, \mathrm{H}_{1^{\prime}}\right), 4.44(\mathrm{~d}, J=$ $15.3 \mathrm{~Hz}, 1 \mathrm{H}, \mathrm{H}_{1^{\prime}}$ ), 4.05 (dd, $J=11.5,2.8 \mathrm{~Hz}, 1 \mathrm{H}, \mathrm{H}_{5}$ ), 3.62 $\left(\mathrm{m}, 1 \mathrm{H}, \mathrm{H}_{3}\right), 3.57\left(\mathrm{~m}, 1 \mathrm{H}, \mathrm{H}_{4}\right), 3.54\left(\mathrm{t}, J=3.3 \mathrm{~Hz}, 1 \mathrm{H}, \mathrm{H}_{2}\right)$, 3.42 (dd, $\left.J=11.5,3.6 \mathrm{~Hz}, 1 \mathrm{H}, \mathrm{H}_{5}\right), 0.90\left(27 \mathrm{H}, \mathrm{CH}_{3(\mathrm{Sit}-\mathrm{Bu})}\right)$, 0.15-0.00 (18H, $\left.\mathrm{CH}_{3(\mathrm{SiMe})}\right) .{ }^{13} \mathrm{C}\left\{{ }^{1} \mathrm{H}\right\}$ NMR $(126 \mathrm{MHz}$, $\left.\mathrm{CDCl}_{3}\right) \delta 132.0\left(\mathrm{C}_{\mathrm{Ar}}\right), 125.3\left(\mathrm{C}_{\mathrm{Ar}}\right), 125.3\left(\mathrm{C}_{\mathrm{Ar}}\right), 99.7\left(\mathrm{C}_{1}\right)$, $87.7\left(\mathrm{C}_{2^{\prime}}\right), 84.8\left(\mathrm{C}_{3^{\prime}}\right), 73.9\left(\mathrm{C}_{3}\right), 73.3\left(\mathrm{C}_{2}\right), 70.4\left(\mathrm{C}_{4}\right), 63.2$ $\left(\mathrm{C}_{5}\right), 54.9\left(\mathrm{C}_{1^{\prime}}\right), 26.3,26.2,26.0\left(\mathrm{CH}_{3(\mathrm{Sit}-\mathrm{Bu})}\right), 18.5,18.4$, $18.0\left(\mathrm{C}_{\mathrm{q}(\mathrm{Sit}-\mathrm{Bu})}\right), \quad 1.2\left(\mathrm{C}_{8^{\prime}}\right),-3.8,-3.9,-4.0,-4.1,-4.6$ $\left(\mathrm{CH}_{3(\mathrm{SiMe})}\right) \cdot{ }^{19} \mathrm{~F}\left\{{ }^{1} \mathrm{H}\right\}$ NMR $\left(471 \mathrm{MHz}, \mathrm{CDCl}_{3}\right) \delta$-62.9. HRMS (EI) $\mathrm{m} / \mathrm{z}$ : $[\mathrm{M}+\mathrm{Na}]^{+}$Calcd for $\mathrm{C}_{33} \mathrm{H}_{57} \mathrm{~F}_{3} \mathrm{O}_{5} \mathrm{NaSi}_{3} 697.3364$; 
Found 697.3365. $[\alpha]^{20}{ }_{\mathrm{D}}=-29\left(c\right.$ 0.476, $\left.\mathrm{CHCl}_{3}\right)$. IR (neat, $\left.\mathrm{cm}^{-1}\right)$ 2929, 2895, 2857, 1471, 1322, 1079, 1065, 774, $657,439$.

Synthesis of 2-(4,4-dimethylpent-2-yn-1-yl)-2,3,4-tri-Otert-butyldimethylsilyl- $\beta$-D-xylopyranoside $\mathbf{3 f}$ in 3 steps (see SI for synthesis scheme).

To a solution of 1,2,3,4-tetra- $O$-acetyl- $\beta$-D-xylopyranose 7 (4.0 g, $12.58 \mathrm{mmol})$ and 4,4-dimethylpent-2-yn-1-ol $(2 \mathrm{~mL}, 15.09 \mathrm{mmol})$ in dry $\mathrm{CH}_{2} \mathrm{Cl}_{2}(30 \mathrm{~mL})$ at $0{ }^{\circ} \mathrm{C}$, was added dropwise $\mathrm{BF}_{3} \cdot \mathrm{Et}_{2} \mathrm{O}$ (2.4 mL, $\left.18.87 \mathrm{mmol}\right)$. The reaction mixture was stirred for $3 \mathrm{~h}$ at $0{ }^{\circ} \mathrm{C}$. The reaction mixture was warmed to r.t. then extracted with $\mathrm{CH}_{2} \mathrm{Cl}_{2}$ (3 times), washed with $10 \% \mathrm{NaHCO}_{3}$ (3 times) and brine (3 times). The organic layer was dried over $\mathrm{MgSO}_{4}$, filtered and concentrated under reduced pressure. The crude residue was purified by flash column chromatography over silica gel (10\% EtOAc in PE) to afford the acetylated xyloside. 8c as a white solid in 68 $\%$ yield $(3.13 \mathrm{~g}, 8.45 \mathrm{mmol}) .{ }^{1} \mathrm{H}$ NMR $\left(600 \mathrm{MHz}, \mathrm{CDCl}_{3}\right) \delta$ $5.19\left(\mathrm{t}, J=8.4 \mathrm{~Hz}, 1 \mathrm{H}, \mathrm{H}_{3}\right), 4.96-4.89\left(2 \mathrm{H}, \mathrm{H}_{2}+\mathrm{H}_{4}\right), 4.74$ (d, $\left.J=6.7 \mathrm{~Hz}, 1 \mathrm{H}, \mathrm{H}_{1}\right), 4.30\left(\mathrm{~s}, 2 \mathrm{H}, \mathrm{H}_{1^{\prime}}\right), 4.12$ (dd, $J=11.9$, $5.0 \mathrm{~Hz}, 1 \mathrm{H}, \mathrm{H}_{5}$ ), 3.39 (dd, $J=11.9,8.5 \mathrm{~Hz}, 1 \mathrm{H}, \mathrm{H}_{5}$ ), 2.07 (s, $\left.3 \mathrm{H}, \mathrm{CH}_{3(\mathrm{OAc})}\right), 2,05\left(\mathrm{~s}, 3 \mathrm{H}, \mathrm{CH}_{3(\mathrm{OAc})}\right), 2.04\left(\mathrm{~s}, 3 \mathrm{H}, \mathrm{CH}_{3(\mathrm{OAc})}\right)$, $1.22\left(\mathrm{~s}, 9 \mathrm{H}, \mathrm{H}_{5}{ }^{\prime}\right) \cdot{ }^{13} \mathrm{C}\left\{{ }^{1} \mathrm{H}\right\}$ NMR $\left(151 \mathrm{MHz}, \mathrm{CDCl}_{3}\right) \delta 170.3$ $(\mathrm{C}=0), 170.0(\mathrm{C}=0), 169.7(\mathrm{C}=0), 97.9\left(\mathrm{C}_{1}\right), 96.4\left(\mathrm{C}_{2^{\prime}}\right)$, $73.0\left(\mathrm{C}_{3^{\prime}}\right), 71.4\left(\mathrm{C}_{3}\right), 70.6\left(\mathrm{C}_{2}\right), 69.1\left(\mathrm{C}_{4}\right), 62.1\left(\mathrm{C}_{5}\right), 56.4$ $\left(\mathrm{C}_{1^{\prime}}\right), 31.0\left(\mathrm{C}_{5^{\prime}}\right), 27.6\left(\mathrm{C}_{4^{\prime}}\right), 21.0,20.9\left(\mathrm{CH}_{3(\mathrm{OAc})}\right)$. HRMS (EI) $\mathrm{m} / \mathrm{z}:[\mathrm{M}+\mathrm{Na}]^{+}$Calcd for $\mathrm{C}_{18} \mathrm{H}_{26} \mathrm{O}_{8} \mathrm{Na} 393.1525$; Found 393.1526. $[\alpha]^{20}{ }_{\mathrm{D}}=-17\left(\mathrm{c} \mathrm{0.6}, \mathrm{CHCl}_{3}\right)$. m.p. $11{ }^{\circ} \mathrm{C}$. IR (neat, $\mathrm{cm}^{-1}$ ) 3320, 2971, 1771, 1444, 1357, 1161, 1104, 1038, 637, 615 .

To a solution of $8 \mathrm{c}(3.13 \mathrm{~g}, 8.45 \mathrm{mmol})$ in methanol (30 $\mathrm{mL})$ was added $\mathrm{Na}(10 \mathrm{mg})$. The mixture was stirred at r.t. for $2 \mathrm{~h}$. The resulting mixture was filtered through a short pad of DOWEX-50H $\mathrm{H}^{+}$resin, concentrated under reduced pressure and the residue was then purified by flash column chromatography over silica gel $(5 \% \mathrm{MeOH}$ in $\mathrm{CH}_{2} \mathrm{Cl}_{2}$ ) to afford the unprotected xylosides $9 \mathbf{c}$ as a white solid in quantitative yield $(2.06 \mathrm{~g}, 8.45 \mathrm{mmol}) .{ }^{1} \mathrm{H}$ NMR (500 MHz, CD $\left.{ }_{3} \mathrm{OD}\right) \delta 4.40\left(\mathrm{~d}, J=7.6 \mathrm{~Hz}, 1 \mathrm{H}, \mathrm{H}_{1}\right)$, $4.28\left(\mathrm{~m}, 2 \mathrm{H}, \mathrm{H}_{1^{\prime}}\right.$ ), 3.88 (dd, $J=11.5,5.3 \mathrm{~Hz}, 1 \mathrm{H}, \mathrm{H}_{5}$ ), 3.49 $\left(\mathrm{m}, 1 \mathrm{H}, \mathrm{H}_{4}\right), 3.31\left(\mathrm{~m}, 1 \mathrm{H}, \mathrm{H}_{3}\right), 3.22-3.16\left(2 \mathrm{H}, \mathrm{H}_{2}+\mathrm{H}_{5}\right)$, $1.23\left(\mathrm{~s}, 9 \mathrm{H},\left(\mathrm{CH}_{3}\right)_{3}\right) .{ }^{13} \mathrm{C}\left\{{ }^{1} \mathrm{H}\right\} \mathrm{NMR}\left(126 \mathrm{MHz}, \mathrm{CD}_{3} \mathrm{OD}\right) \delta$ $102.7\left(\mathrm{C}_{1}\right), 96.4\left(\mathrm{C}_{2^{\prime}}\right), 77.7\left(\mathrm{C}_{3}\right), 74.9\left(\mathrm{C}_{3^{\prime}}\right), 74.6\left(\mathrm{C}_{2}\right), 71.2$ $\left(\mathrm{C}_{4}\right), 66.9\left(\mathrm{C}_{5}\right), 57.1\left(\mathrm{C}_{1^{\prime}}\right), 31.3\left(\mathrm{C}_{5^{\prime}}\right), 28.4\left(\mathrm{C}_{4^{\prime}}\right)$. HRMS (EI) for $\mathrm{C}_{12} \mathrm{H}_{20} \mathrm{O}_{5} \mathrm{Na}$ : calc. $(\mathrm{m} / \mathrm{z}) 267.1208$; found $(\mathrm{m} / \mathrm{z})$ 267.1215. $[\alpha]^{20}{ }_{\mathrm{D}}=-21\left(\mathrm{c} 0.7, \mathrm{CH}_{3} \mathrm{OH}\right) ;$ m.p. $102{ }^{\circ} \mathrm{C}$. IR (neat, $\mathrm{cm}^{-1}$ ) 3306, 2971, 2925, 2864, 1444, 1359, 1248, 1138, 1071, 1053, 615.

According to the synthesis of $\mathbf{2}$, unprotected D-xyloside 9c $(230 \mathrm{mg}, 0.87 \mathrm{mmol}$ ), imidazole (300 mg, 4.35 mmol), TBSCl (530 mg, $3.48 \mathrm{mmol}$ ) and DMAP (5 mg, $0.02 \mathrm{mmol} \mathrm{ca}$ ) were reacted in DMF (1 mL) to afford product $\mathbf{3 f}$ as a colorless oil in $97 \%$ yield $(501 \mathrm{mg}, 0.85$ mmol). $\left.{ }^{1} \mathrm{H} \mathrm{NMR} \mathrm{(500} \mathrm{MHz,} \mathrm{CDCl}_{3}\right) \delta 4.70(\mathrm{~d}, J=3.4 \mathrm{~Hz}$, $\left.1 \mathrm{H}, \mathrm{H}_{1}\right), 4.23\left(\mathrm{~d}, J=15.0 \mathrm{~Hz}, 1 \mathrm{H}, \mathrm{H}_{1^{\prime}}\right), 4.16(\mathrm{~d}, J=15.0 \mathrm{~Hz}$, $\left.1 \mathrm{H}, \mathrm{H}_{1^{\prime}}\right), 3.99$ (dd, $\left.J=11.5,3.0 \mathrm{~Hz}, 1 \mathrm{H}, \mathrm{H}_{5}\right), 3.59(\mathrm{~m}, 1 \mathrm{H}$, $\left.\mathrm{H}_{3}\right), 3.54\left(\mathrm{~m}, 1 \mathrm{H}, \mathrm{H}_{4}\right), 3.49$ (t, $\left.J=3.4 \mathrm{~Hz}, 1 \mathrm{H}, \mathrm{H}_{2}\right), 3.36$ (dd, $J=11.5,4.0 \mathrm{~Hz}, 1 \mathrm{H}, \mathrm{H}_{5}$ ), 1.20 (s, 9H, $\left.\mathrm{H}_{5^{\prime}}\right), 0.96-0.85$ (27H, CH 3 (Sit-Bu) $), 0.14-0.04$ (18H, CH $\left.\mathrm{CH}_{3(\mathrm{SiMe})}\right) \cdot{ }^{13} \mathrm{C}\left\{{ }^{1} \mathrm{H}\right\} \mathrm{NMR}$ $\left(126 \mathrm{MHz}, \mathrm{CDCl}_{3}\right) \delta 99.2\left(\mathrm{C}_{1}\right), 95.0\left(\mathrm{C}_{2^{\prime}}\right), 74.2\left(\mathrm{C}_{3}\right), 74.1$ $\left(\mathrm{C}_{3^{\prime}}\right), 73.4\left(\mathrm{C}_{2}\right), 70.6\left(\mathrm{C}_{4}\right), 63.1\left(\mathrm{C}_{5}\right), 54.8\left(\mathrm{C}_{1^{\prime}}\right), 31.1\left(\mathrm{C}_{5^{\prime}}\right)$, 26.4, 26.3, $26.1\left(\mathrm{CH}_{3(\mathrm{Sit}-\mathrm{Bu})}\right), 22.7\left(\mathrm{C}_{4^{\prime}}\right), 18.5,18.0\left(\mathrm{C}_{\mathrm{q}(\mathrm{Sit}-}\right.$ $\mathrm{Bu})$ ) $-3.7,-3.9,-4.0,-4.5\left(\mathrm{CH}_{3(\mathrm{SiMe})}\right)$. HRMS (EI) m/z: $[\mathrm{M}+\mathrm{Na}]^{+}$Calcd for $\mathrm{C}_{30} \mathrm{H}_{62} \mathrm{O}_{5} \mathrm{NaSi}_{3}$ 609.3796; Found 609.3803. $[\alpha]^{20}{ }_{\mathrm{D}}=-30\left(c 1.06, \mathrm{CHCl}_{3}\right)$. IR (neat, $\mathrm{cm}^{-1}$ ) 2953, 2856, 1472, 1251, 1085, 1011, 969, 832.

\section{General procedure for the synthesis of disubstituted allenes 4a-f}

To a solution of the propargyl xyloside 3a-f (1 eq.) and TMEDA (1.1 eq.) in $\mathrm{Et}_{2} \mathrm{O}$ at $-78{ }^{\circ} \mathrm{C}$ was added $s$-BuLi (1.1 eq.). The resulting mixture was stirred at $-78^{\circ} \mathrm{C}$ for $1 \mathrm{~h}$, and then the temperature was decreased to reach -115 ${ }^{\circ} \mathrm{C}$. After $30 \mathrm{~min}$ at $-115{ }^{\circ} \mathrm{C}$, a solution of $t$ - $\mathrm{BuOH}(20$ eq.) in $\mathrm{Et}_{2} \mathrm{O}$ was added dropwise. The reaction mixture was stirred over $1 \mathrm{~h}$, warmed to r.t. and diluted with diethyl ether and water. The two phases were separated and the aqueous phase was extracted again with ether. The combined organic extracts were washed with $10 \%$ $\mathrm{NaHCO}_{3}$ and brine, dried over $\mathrm{MgSO}_{4}$, filtered and concentrated under reduced pressure to afford the crude product as a mixture of allenes (two diasteroisomers $(\mathrm{a} S):(\mathrm{a} R))$ /propargyl.

Synthesis of 2-(buta-1,2-dien-1-yl)-2,3,4-tri-O-tbutyldimethylsilyl- $\beta$-D-xylopyranoside $4 \mathbf{a}$. According to the general procedure, 3a (177 $\mathrm{mg}, 0.325 \mathrm{mmol})$, TMEDA (0.1 mL, $0.65 \mathrm{mmol}), s$-BuLi $(0.46 \mathrm{~mL}, 0.65$ $\mathrm{mmol})$ and $t$-BuOH $(1 \mathrm{~mL})$ were reacted in $\mathrm{Et}_{2} \mathrm{O}(4 \mathrm{~mL}+$ $2 \mathrm{~mL})$ to obtain the crude product $(177 \mathrm{mg})$ as a mixture of allenes 4a- $(\mathrm{a} S) /(\mathrm{a} R)$ (93:7) /propargyl (91:9). The crude product was purified by flash column chromatography over silica gel $\left(1 \% \mathrm{Et}_{2} \mathrm{O}, 1 \% \mathrm{Et}_{3} \mathrm{~N}\right.$ in $\left.\mathrm{PE}\right)$ and the major diastereoisomer of the allenes 4a- $(\mathrm{a} S)$ was isolated as a white solid (158.6 mg, 75\%). Diastereoisomer 4a-(aS): ${ }^{1} \mathrm{H}$ NMR $\left(500 \mathrm{MHz}, \mathrm{CDCl}_{3}\right) \delta 6.47(\mathrm{qd}$, $J=5.5,2.3 \mathrm{~Hz}, 1 \mathrm{H}, \mathrm{H}_{1^{\prime}}$ ), $5.70\left(\mathrm{qd}, J=6.9,5.5 \mathrm{~Hz}, 1 \mathrm{H}, \mathrm{H}_{3^{\prime}}\right.$ ), $4.77\left(\mathrm{~d}, J=4.3 \mathrm{~Hz}, 1 \mathrm{H}, \mathrm{H}_{1}\right), 4.04(\mathrm{dd}, J=11.6,3.4 \mathrm{~Hz}, 1 \mathrm{H}$, $\mathrm{H}_{5}$ ), 3.60-3.58 (3H, $\left.\mathrm{H}_{2}+\mathrm{H}_{3}+\mathrm{H}_{4}\right), 3.39$ (dd, $J=11.6,5.0$ $\mathrm{Hz}, 1 \mathrm{H}, \mathrm{H}_{5}$ ), 1.75 (dd, $J=6.9,2.3 \mathrm{~Hz}, 3 \mathrm{H}, \mathrm{CH}_{3 \text { (allene) }), 0.91-}$ $0.88\left(27 \mathrm{H}, \mathrm{CH}_{3(\mathrm{Sit}-\mathrm{Bu})}\right), 0.09-0.07\left(18 \mathrm{H}, \mathrm{CH}_{3(\mathrm{SiMe})}\right) .{ }^{13} \mathrm{C}\left\{{ }^{1} \mathrm{H}\right\}$ NMR (126 MHz, $\left.\mathrm{CDCl}_{3}\right) \delta 194.9\left(\mathrm{C}_{2^{\prime}}\right), 117.4\left(\mathrm{C}_{1^{\prime}}\right), 100.9$ $\left(\mathrm{C}_{3^{\prime}}\right), 100.1\left(\mathrm{C}_{1}\right), 74.9\left(\mathrm{C}_{4}\right), 73.5\left(\mathrm{C}_{2}\right), 70.8\left(\mathrm{C}_{3}\right), 64.4\left(\mathrm{C}_{5}\right)$, 26.0, 26.1, 26.2, $26.3\left(\mathrm{CH}_{3(\mathrm{Sit}-\mathrm{Bu})}\right), 18.5,18.4\left(\mathrm{C}_{\mathrm{q}(\mathrm{Sit}-\mathrm{Bu})}\right)$, $16.8\left(\mathrm{CH}_{3 \text { (allene) }),-3.6,-3.8,-3.9,-4.1,-4.6}\left(\mathrm{CH}_{3(\mathrm{SiMe})}\right)\right.$. HRMS (EI) for $\mathrm{C}_{27} \mathrm{H}_{56} \mathrm{O}_{5} \mathrm{NaSi}_{3}$ : calc. (m/z) 567.3333; found $(\mathrm{m} / \mathrm{z}) 567.3329 .[\alpha]^{20}{ }_{\mathrm{D}}=-5.5\left(c \mathrm{0} 61, \mathrm{CHCl}_{3}\right)$. m.p. $54{ }^{\circ} \mathrm{C}$. IR (neat, $\mathrm{cm}^{-1}$ ) 2891, 2931, 2836, 1981, 1471, 1250, 830. Anal. Calcd for $\mathrm{C}_{27} \mathrm{H}_{56} \mathrm{O}_{5} \mathrm{Si}_{3}: \mathrm{C}, 59.50 ; \mathrm{H}$, 10.36. Found: C, $59.30 ; \mathrm{H}, 10.66$. 
Synthesis of the 2-(3-trimethylsilylpropa-1,2-dien-1-yl)2,3,4-tri-O-t-butyldimethylsilyl- $\beta$-D-xylopyranoside $\mathbf{4} \mathbf{b}$. According to the general procedure, 3b $(159 \mathrm{mg}, 0.26$ mmol), TMEDA (0.08 mL, $0.52 \mathrm{mmol}), s$-BuLi $(0.1 \mathrm{~mL}$, $0.52 \mathrm{mmol})$ and $t$ - $\mathrm{BuOH}(0.3 \mathrm{~mL})$ were reacted in $\mathrm{Et}_{2} \mathrm{O}$ $(1 \mathrm{~mL}+0.6 \mathrm{~mL})$ to obtain the crude product $\mathbf{4 b}(159$ $\mathrm{mg}$ ) as a mixture of allenes (d.r.: 70:30) /propargyl (42:58). Due to the small difference in polarity between $\mathbf{3 b}$ and $\mathbf{4 b}$, these products could not be separated by column chromatography. However, attempts to assign signals are given below from a spectrum of a crude reaction mixture. Diastereoisomer 4b-(aS): ${ }^{1} \mathrm{H}$ NMR $\left(500 \mathrm{MHz}, \mathrm{CDCl}_{3}\right) \delta 6.48\left(\mathrm{~d}, J=6.4 \mathrm{~Hz}, 1 \mathrm{H}, \mathrm{H}_{1^{\prime}}\right), 5.83(\mathrm{~d}, J$ $\left.=6.4 \mathrm{~Hz}, 1 \mathrm{H}, \mathrm{H}_{3^{\prime}}\right), 4.65\left(\mathrm{~d}, J=4.2 \mathrm{~Hz}, 1 \mathrm{H}, \mathrm{H}_{1}\right), 3.99(\mathrm{dd}, J=$ 11.4, $\left.2.8 \mathrm{~Hz}, 1 \mathrm{H}, \mathrm{H}_{5}\right), 3.60-3.47\left(3 \mathrm{H}, \mathrm{H}_{3}+\mathrm{H}_{2}+\mathrm{H}_{4}\right), 3.37$ (dd, $\left.J=11.4,3.3 \mathrm{~Hz}, 1 \mathrm{H}, \mathrm{H}_{5}\right), 0.92-0.86\left(27 \mathrm{H}, \mathrm{CH}_{3(\mathrm{Sit}-\mathrm{Bu})}\right)$,

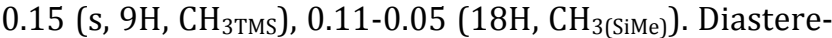
oisomer 4b-(aR): ${ }^{1} \mathrm{H}$ NMR $\left(500 \mathrm{MHz}, \mathrm{CDCl}_{3}\right) \delta 6.53(\mathrm{~d}, J$ $\left.=6.4 \mathrm{~Hz}, 1 \mathrm{H}, \mathrm{H}_{1^{\prime}}\right), 5.86\left(\mathrm{~d}, J=6.4 \mathrm{~Hz}, 1 \mathrm{H} \mathrm{H}_{3^{\prime}}\right), 4.67(\mathrm{~d}, J=$ $3.1 \mathrm{~Hz}, 1 \mathrm{H}, \mathrm{H}_{1}$ ), 3.99 (dd, $J=11.4,2.8 \mathrm{~Hz}, 1 \mathrm{H}, \mathrm{H}_{5}$ ), $3.60-$ $3.47\left(3 \mathrm{H}, \mathrm{H}_{3}+\mathrm{H}_{2}+\mathrm{H}_{4}\right), 3.37$ (dd, $J=11.4,3.3 \mathrm{~Hz}, 1 \mathrm{H}$, $\left.\mathrm{H}_{5}\right), 0.92-0.86\left(27 \mathrm{H}, \mathrm{CH}_{3(\mathrm{Sit}-\mathrm{Bu})}\right), 0.15$ (s, 9H, $\left.\mathrm{CH}_{3 \mathrm{TMS}}\right)$, $0.11-0.05\left(18 \mathrm{H}, \mathrm{CH}_{3(\mathrm{SiMe})}\right)$.

Synthesis of 2-(3-phenylpropa-1,2-dien-1-yl)-2,3,4-tri-O-tbutyldimethylsilyl- $\beta$-D-xylopyranoside 4c. According to the general procedure, $3 \mathrm{c}(76 \mathrm{mg}, 0.12 \mathrm{mmol})$, TMEDA $(0.02 \mathrm{~mL}, 0.13 \mathrm{mmol}), s$-BuLi $(0.1 \mathrm{~mL}, 0.13 \mathrm{mmol})$ and $t$ $\mathrm{BuOH}(0.4 \mathrm{~mL})$ were reacted in $\mathrm{Et}_{2} \mathrm{O}(1 \mathrm{~mL}+0.8 \mathrm{~mL})$ to obtain the crude product $4 \mathbf{c}(75 \mathrm{mg})$ as a mixture of allenes $(\mathrm{a} S) /(\mathrm{a} R)$ (70:30)/propargyl (65:35). The allenes were not isolated from the propargyl 3c, due to their low stability over time and over silica gel (or alumina). However, attempts to assign signals are given below from a spectrum of a crude reaction mixture. Diastereoisomer 4c-(aS): ${ }^{1} \mathrm{H}$ NMR $\left(500 \mathrm{MHz}, \mathrm{CDCl}_{3}\right) \delta$ 7.42-7.29 (5H, $\left.\mathrm{H}_{\mathrm{Ar}}\right), 6.94\left(\mathrm{~d}, J=5.7 \mathrm{~Hz}, 1 \mathrm{H}, \mathrm{H}_{1^{\prime}}\right), 6.66(\mathrm{~d}, J$ $\left.=5.6 \mathrm{~Hz}, 1 \mathrm{H}, \mathrm{H}_{3^{\prime}}\right), 4.82\left(\mathrm{~d}, J=3.2 \mathrm{~Hz}, 1 \mathrm{H}, \mathrm{H}_{1}\right), 4.05(\mathrm{~m}$, $\left.1 \mathrm{H}, \mathrm{H}_{5}\right), 3.62-3.50\left(3 \mathrm{H}, \mathrm{H}_{3}+\mathrm{H}_{2}+\mathrm{H}_{4}\right), 3.34(\mathrm{dd}, J=11.5$, $\left.3.6 \mathrm{~Hz}, 1 \mathrm{H}, \mathrm{H}_{5}\right), 0.90-0.84\left(27 \mathrm{H}, \mathrm{CH}_{3(\mathrm{Sit}-\mathrm{Bu})}\right), 0.12-0.08$ $\left(18 \mathrm{H}, \mathrm{CH}_{3(\mathrm{SiMe})}\right)$. Diastereoisomer 4c-(aR): ${ }^{1} \mathrm{H}$ NMR (500 $\left.\mathrm{MHz}, \mathrm{CDCl}_{3}\right) \delta 7.42-7.29\left(5 \mathrm{H}, \mathrm{H}_{\mathrm{Ar}}\right), 6.94(\mathrm{~d}, J=5.7 \mathrm{~Hz}, 1 \mathrm{H}$, $\left.\mathrm{H}_{1^{\prime}}\right), 6.76\left(\mathrm{~d}, J=5.6 \mathrm{~Hz}, 1 \mathrm{H}, \mathrm{H}_{3^{\prime}}\right), 4.86(\mathrm{~d}, J=3.2 \mathrm{~Hz}, 1 \mathrm{H}$, $\left.\mathrm{H}_{1}\right)$.

Synthesis of 2-(3-(p-methoxy)propa-1,2-dien-1-yl)-2,3,4tri-O-t-butyldimethylsilyl- $\beta$-D-xylopyranoside 4d. According to the general procedure, $3 \mathbf{d}(62 \mathrm{mg}, 0.1 \mathrm{mmol})$, TMEDA $(0.05 \mathrm{~mL}, 0.12 \mathrm{mmol}), s$-BuLi $(0.1 \mathrm{~mL}, 0.13$ mmol) and $t$-BuOH $(0.3 \mathrm{~mL})$ were reacted in $\mathrm{Et}_{2} \mathrm{O}(1 \mathrm{~mL}$ $+0.6 \mathrm{~mL})$ to obtain the crude product $4 \mathbf{d d}(62 \mathrm{mg})$ as a mixture of allenes $(a S) /(a R)(70: 30) /$ propargyl (50:50). The allenes were not isolated from the propargyl 3d, due to their low stability over time and on silica gel (or alumina). However, attempts to assign signals are given below from a spectrum of a crude reaction mixture. Diastereoisomer 4d-(aS): ${ }^{1} \mathrm{H}$ NMR $\left(500 \mathrm{MHz}, \mathrm{CDCl}_{3}\right) \delta$ $7.35\left(\mathrm{~d}, J=8.4 \mathrm{~Hz}, 2 \mathrm{H}, \mathrm{H}_{\mathrm{Ar}}\right), 6.90\left(\mathrm{~d}, J=5.7 \mathrm{~Hz}, 1 \mathrm{H}, \mathrm{H}_{1^{\prime}}\right)$, $6.84\left(\mathrm{~d}, J=8.4 \mathrm{~Hz}, 2 \mathrm{H}, \mathrm{H}_{\mathrm{Ar}}\right), 6.62\left(\mathrm{~d}, J=5.6 \mathrm{~Hz}, 1 \mathrm{H}, \mathrm{H}_{3^{\prime}}\right)$, $4.82\left(\mathrm{~d}, J=2.9 \mathrm{~Hz}, 1 \mathrm{H}, \mathrm{H}_{1}\right), 4.03\left(\mathrm{~m}, 1 \mathrm{H}, \mathrm{H}_{5}\right), 3.81(\mathrm{~s}, 3 \mathrm{H}$, $\left.\mathrm{OCH}_{3}\right), 3.57-3.46\left(3 \mathrm{H}, \mathrm{H}_{3}+\mathrm{H}_{2}+\mathrm{H}_{4}\right), 3.33\left(\mathrm{~m}, 1 \mathrm{H}, \mathrm{H}_{5}\right)$, 0.94-0.85 (27H, CH 3 (Sit-Bu)), 0.13-0.07 (18H, $\mathrm{CH}_{3(\mathrm{SiMe}))}$. Diastereoisomer 4d-(aR): ${ }^{1} \mathrm{H}$ NMR $\left(500 \mathrm{MHz}, \mathrm{CDCl}_{3}\right) \delta$ $7,35\left(\mathrm{~d}, J=8.4 \mathrm{~Hz}, 2 \mathrm{H}, \mathrm{H}_{\mathrm{Ar}}\right), 6.90\left(\mathrm{~d}, J=5.7 \mathrm{~Hz}, 1 \mathrm{H}, \mathrm{H}_{1^{\prime}}\right)$, $6.84\left(\mathrm{~d}, J=8.4 \mathrm{~Hz}, 2 \mathrm{H}, \mathrm{H}_{\mathrm{Ar}}\right), 6.72\left(\mathrm{~d}, J=5.6 \mathrm{~Hz}, 1 \mathrm{H}, \mathrm{H}_{3^{\prime}}\right)$, $4.85\left(\mathrm{~d}, J=2.9 \mathrm{~Hz}, 1 \mathrm{H}, \mathrm{H}_{1}\right), 4.03\left(\mathrm{~m}, 1 \mathrm{H}, \mathrm{H}_{5}\right), 3.81(\mathrm{~s}, 3 \mathrm{H}$, $\left.\mathrm{OCH}_{3}\right), 3.57-3.46\left(3 \mathrm{H}, \mathrm{H}_{3}+\mathrm{H}_{2}+\mathrm{H}_{4}\right), 0.94-0.85(27 \mathrm{H}$, $\left.\mathrm{CH}_{3(\mathrm{Sit}-\mathrm{Bu})}\right), 0.13-0.07$ (18H, $\left.\mathrm{CH}_{3(\mathrm{SiMe})}\right)$.

Synthesis of the 2-(3-(4-(trifluoromethyl)phenyl)propa1,2-dien-1-yl)-2,3,4-tri-O-t-butyldimethylsilyl- $\beta$-D-

xylopyranoside 4e. According to the general procedure, 3 e $(52 \mathrm{mg}, 0.08 \mathrm{mmol})$, TMEDA (0.05 $\mathrm{mL}, 0.09 \mathrm{mmol})$, $s$-BuLi $(0.07 \mathrm{~mL}, 0.09 \mathrm{mmol})$ and $t$-BuOH $(0.3 \mathrm{~mL})$ were reacted in $\mathrm{Et}_{2} \mathrm{O}(1 \mathrm{~mL}+0.6 \mathrm{~mL})$ to obtain the crude product $4 \mathbf{e}$ as a mixture of allenes $(\mathrm{a} S) /(\mathrm{a} R)(55: 45)$. The allenes were not isolated in a pure form, due to their low stability over time and on silica gel (or alumina). However, attempts to assign some signals are given below from a spectrum of a crude reaction mixture. Diastereoisomer 4e-(aS): ${ }^{1} \mathrm{H}$ NMR $\left(500 \mathrm{MHz}, \mathrm{CDCl}_{3}\right) \delta$ $7.55\left(\mathrm{~d}, J=8.0 \mathrm{~Hz}, 2 \mathrm{H}, \mathrm{H}_{\mathrm{Ar}}\right), 7.46\left(\mathrm{~m}, 2 \mathrm{H}, \mathrm{H}_{\mathrm{Ar}}\right), 7.00(\mathrm{~d}, J=$ $5.6 \mathrm{~Hz}, 2 \mathrm{H}, \mathrm{H}_{1^{\prime}}$ ), $6.67\left(\mathrm{~d}, J=5.6 \mathrm{~Hz}, 1 \mathrm{H}, \mathrm{H}_{3^{\prime}}\right), 4.86$ (d, $J=$ $\left.3.2 \mathrm{~Hz}, 1 \mathrm{H}, \mathrm{H}_{1}\right) .{ }^{19} \mathrm{~F}\left\{{ }^{1} \mathrm{H}\right\} \mathrm{NMR}\left(471 \mathrm{MHz}, \mathrm{CDCl}_{3}\right) \delta-62.4$. Diastereoisomer 4e-(aR): ${ }^{1} \mathrm{H}$ NMR $\left(500 \mathrm{MHz}, \mathrm{CDCl}_{3}\right) \delta$ $7.55\left(\mathrm{~d}, J=8.0 \mathrm{~Hz}, 2 \mathrm{H}, \mathrm{H}_{5^{\prime}}\right), 7.46\left(\mathrm{~m}, 2 \mathrm{H}, \mathrm{H}_{6^{\prime}}\right), 7.00(\mathrm{~d}, J=$ $\left.5.6 \mathrm{~Hz}, 2 \mathrm{H}, \mathrm{H}_{1^{\prime}}\right), 6.78\left(\mathrm{~d}, J=5.7 \mathrm{~Hz}, 1 \mathrm{H}, \mathrm{H}_{3^{\prime}}\right), 4.88(\mathrm{~d}, J=$ $\left.3.2 \mathrm{~Hz}, 1 \mathrm{H}, \mathrm{H}_{1}\right) .{ }^{19} \mathrm{~F}\left\{{ }^{1} \mathrm{H}\right\}$ NMR $\left(471 \mathrm{MHz}, \mathrm{CDCl}_{3}\right) \delta-62.5$.

Synthesis of 2-(4,4-dimethylpenta-1,2-dien-1-yl)-2,3,4-tri$O$-t-butyldimethylsilyl- $\beta$ - $D$-xylopyranoside 4f. According to the general procedure, 3 f $(90 \mathrm{mg}, 0.17 \mathrm{mmol}$ ), TMEDA (0.1 mL, $0.25 \mathrm{mmol}), s$-BuLi $(0.25 \mathrm{~mL}, 0.25$ $\mathrm{mmol})$ and $t-\mathrm{BuOH}(0.25 \mathrm{~mL})$ were reacted in $\mathrm{Et}_{2} \mathrm{O}(1$ $\mathrm{mL}+0.5 \mathrm{~mL})$ to obtain the crude $(90 \mathrm{mg})$ as a mixture of allene $(\mathrm{a} S):(\mathrm{a} R)(80: 20)$. The crude product was purified by flash column chromatography on silica gel $(1 \%$ $\mathrm{Et}_{2} \mathrm{O}, 1 \% \mathrm{Et}_{3} \mathrm{~N}$ in PE) and a small amount of the major diastereoisomer of the allenes $\mathbf{4 f -}(\mathrm{a} S)$ was isolated in a pure form as a white solid (13 $\mathrm{mg}, 14 \%$ ) and mixture of allenes (75 mg). Diastereoisomer 4f-(aS): ${ }^{1} \mathrm{H}$ NMR (500 $\left.\mathrm{MHz}, \mathrm{CDCl}_{3}\right) \delta 6.57\left(\mathrm{~d}, J=5.6 \mathrm{~Hz}, 1 \mathrm{H}, \mathrm{H}_{1^{\prime}}\right), 5.80(\mathrm{~d}, J=5.6$ $\mathrm{Hz}, 1 \mathrm{H}, \mathrm{H}_{3^{\prime}}$ ), 4.75 (d, $J=3.4 \mathrm{~Hz}, 1 \mathrm{H}, \mathrm{H}_{1}$ ), 4.04 (dd, $J=11.8$, $\left.2.9 \mathrm{~Hz}, 1 \mathrm{H}, \mathrm{H}_{5}\right), 3.62-3.56\left(3 \mathrm{H}, \mathrm{H}_{3}+\mathrm{H}_{2}+\mathrm{H}_{4}\right), 3.39$ (dd, $J=$ 11.8, $3.7 \mathrm{~Hz}, 1 \mathrm{H}, \mathrm{H}_{5}$ ), 1.04 (s, 9H, $\left.\mathrm{CH}_{3(t-\mathrm{Bu})}\right), 0.93-0.87$ (27H, $\left.\mathrm{CH}_{3(\mathrm{Sit}-\mathrm{Bu})}\right), 0.10-0.04\left(18 \mathrm{H}, \mathrm{CH}_{3(\mathrm{SiMe})}\right) .{ }^{13} \mathrm{C}\left\{{ }^{1} \mathrm{H}\right\} \mathrm{NMR}$ $\left(126 \mathrm{MHz}, \mathrm{CDCl}_{3}\right) \delta 190.2\left(\mathrm{C}_{2^{\prime}}\right), 119.1\left(\mathrm{C}_{1^{\prime}}\right), 117.3\left(\mathrm{C}_{3^{\prime}}\right)$, $99.9\left(\mathrm{C}_{1}\right), 74.2\left(\mathrm{C}_{4}\right), 73.2\left(\mathrm{C}_{2}\right), 70.5\left(\mathrm{C}_{3}\right), 63.6\left(\mathrm{C}_{5}\right), 33.2$ $\left(\mathrm{C}_{\mathrm{q}(t-\mathrm{Bu} \text {,allene })}\right), 29.7\left(\mathrm{CH}_{3(t-\mathrm{Bu}, \text { allene })}\right), 26.3,26.1\left(\mathrm{CH}_{3(\mathrm{Sit}-\mathrm{Bu})}\right)$, 18.5, $18.4\left(\mathrm{C}_{\mathrm{q}(\mathrm{Sit}-\mathrm{Bu})}\right),-3.7,-3.9,-4.0,-4.2,-4.5\left(\mathrm{CH}_{3(\mathrm{SiMe})}\right)$. HRMS (EI) m/z: [M+Na] ${ }^{+}$Calcd for $\mathrm{C}_{30} \mathrm{H}_{62} \mathrm{O}_{5} \mathrm{NaSi}_{3}$ 609.3803; Found 697.3815. $[\alpha]^{20} \mathrm{D}-19.4$ (c 0.175 , $\mathrm{CHCl}_{3}$ ).

General procedure for synthesis of methoxyprotected propargyl xylosides $5 a$ and $5 b$ in 3 steps (see SI for synthetic scheme). 
To a solution of 1,2,3,4-tetra-0-acetyl- $\beta$-D-xylopyranose 7 and the corresponding propargyl alcohol (1.2 eq.) in dry $\mathrm{CH}_{2} \mathrm{Cl}_{2}$ at $0{ }^{\circ} \mathrm{C}$, was added dropwise $\mathrm{BF}_{3} \cdot \mathrm{Et}_{2} \mathrm{O}(1.5$ eq.). The reaction mixture was stirred for $3 \mathrm{~h}$ at $0{ }^{\circ} \mathrm{C}$. The reaction mixture was warmed to r.t. then extracted with $\mathrm{CH}_{2} \mathrm{Cl}_{2}$ (3 times), washed with $10 \% \mathrm{NaHCO}_{3}$ (3 times) and brine (3 times). The organic layer was dried over $\mathrm{MgSO}_{4}$, filtered and concentrated under reduced pressure. The crude residue was purified by flash column chromatography over silica gel (10\% EtOAc in PE) to afford the corresponding acetylated xylosides $\mathbf{8 a}$,b.

To a solution of the acetylated xyloside derivatives $\mathbf{8 a}, \mathbf{b}$ in methanol was added $\mathrm{Na}(0.3 \mathrm{eq}$.). The mixture was stirred at r.t. for $2 \mathrm{~h}$. The resulting mixture was filtered through a short pad of DOWEX-50H ${ }^{+}$resin, concentrated under reduced pressure and the residue was then purified by flash column chromatography over silica gel (5\% $\mathrm{MeOH}$ in $\mathrm{CH}_{2} \mathrm{Cl}_{2}$ ) to afford the unprotected xylosides $\mathbf{9 a , b}$.

For the methylation, a literature procedure known for galactosides was modified for xylosides. ${ }^{28}$ To a solution of unprotected D-xylosides 9a,b (1 eq.) in dry acetonitrile ( $1 \mathrm{~mL} / 0.06 \mathrm{mmol})$, was added MeI (20 eq.), followed by $\mathrm{Ag}_{2} \mathrm{O}(1.2 \mathrm{mmol} / \mathrm{OH})$ and a catalytic amount of $\mathrm{Me}_{2} \mathrm{~S}$. The mixture was stirred in the dark at room temperature. After $21 \mathrm{~h}$, the reaction mixture was diluted with water. The aqueous phase was extracted with EtOAc and the combined organic extracts were washed with brine and dried over $\mathrm{MgSO}_{4}$. The crude residue was purified by flash column chromatography over silica gel (10\% EtOAc in PE) to afford the corresponding methylated xyloside $\mathbf{5 a}, \mathbf{b}$.

Synthesis of the (but-2-ynyl)-2,3,4-tri-O-acetyl- $\beta$-Dxylopyranoside 8a. According to the general procedure, 1,2,3,4-tetra- $O$-acetyl- $\beta$-D-xylopyranose 7 (6.0 g, 18.86 mmol), but-2-yn-1-ol (1.7 mL, $22.63 \mathrm{mmol})$ and $\mathrm{BF}_{3} \cdot \mathrm{Et}_{2} \mathrm{O}$ (3.53 mL, $28.29 \mathrm{mmol}$ ) were reacted in $\mathrm{CH}_{2} \mathrm{Cl}_{2}$ $(50 \mathrm{~mL})$ to afford product $\mathbf{8 a}$ as a white solid in $92 \%$ yield (5.69 g, $17.35 \mathrm{mmol}) .{ }^{1} \mathrm{H}$ NMR $\left(500 \mathrm{MHz} \mathrm{CDCl}_{3}\right) \delta$ $5.19\left(\mathrm{t}, J=8.5 \mathrm{~Hz}, 1 \mathrm{H}, \mathrm{H}_{3}\right), 4.97-4.88\left(2 \mathrm{H}, \mathrm{H}_{2}+\mathrm{H}_{4}\right), 4.73$ (d, $\left.J=6.8 \mathrm{~Hz}, 1 \mathrm{H}, \mathrm{H}_{1}\right), 4.28\left(\mathrm{q}, J=2.4 \mathrm{~Hz}, 2 \mathrm{H}, \mathrm{H}_{1^{\prime}}\right), 4.14$ (dd, $J=11.9,5.1 \mathrm{~Hz}, 1 \mathrm{H}, \mathrm{H}_{5}$ ), 3.39 (dd, $J=11.9,8.6 \mathrm{~Hz}$, $\left.1 \mathrm{H}, \mathrm{H}_{5}\right), 2.07$ (s, 3H, $\left.\mathrm{CH}_{3(\mathrm{OAc})}\right), 2.05$ (s, 3H, $\left.\mathrm{CH}_{3(\mathrm{OAc})}\right), 2.04$ $\left(\mathrm{s}, 3 \mathrm{H}, \mathrm{CH}_{3(\mathrm{OAc})}\right), 1.86\left(\mathrm{t}, J=2.4 \mathrm{~Hz}, 3 \mathrm{H}, \mathrm{H}_{4^{\prime}}\right) \cdot{ }^{13} \mathrm{C}\left\{{ }^{1} \mathrm{H}\right\} \mathrm{NMR}$

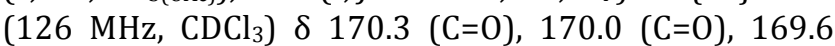
$(\mathrm{C}=0), 98.2\left(\mathrm{C}_{1}\right), 83.6\left(\mathrm{C}_{2^{\prime}}\right), 73.8\left(\mathrm{C}_{3^{\prime}}\right), 71.5\left(\mathrm{C}_{3}\right), 70.7$ $\left(\mathrm{C}_{2}\right), 69.0\left(\mathrm{C}_{4}\right), 62.2\left(\mathrm{C}_{5}\right), 56.4\left(\mathrm{C}_{1^{\prime}}\right), 20.9,20.8\left(\mathrm{CH}_{3(\mathrm{OAc})}\right)$, $3.8\left(\mathrm{C}_{4}{ }^{\prime}\right)$. HRMS (EI) m/z: $[\mathrm{M}+\mathrm{Na}]^{+}$Calcd for $\mathrm{C}_{15} \mathrm{H}_{20} \mathrm{O}_{8} \mathrm{Na}$ 351.1050; Found 351.1056. $[\alpha]^{20} \mathrm{D}=-29$ (c 0.752, $\mathrm{CHCl}_{3}$ ); m.p. $108{ }^{\circ} \mathrm{C}$; IR (neat, $\mathrm{cm}^{-1}$ ) 2927, 2822,1744 , $1460,1368,1219,1157,1046,904,879$.

Synthesis of (3-(4-fluorophenyl)prop-2-ynyl)-2,3,4-tri-Oacetyl- $\beta$-D-xylopyranoside $\mathbf{8 b}$. According to the general procedure, 1,2,3,4-tetra- $O$-acetyl- $\beta$-D-xylopyranose 7 (668 mg, $2.16 \mathrm{mmol}$ ), 3-(4-fluorophenyl)prop-2-yn-1-ol
(357 $\mathrm{mg}, 2.38 \mathrm{mmol}$ ) and $\mathrm{BF}_{3} \cdot \mathrm{Et}_{2} \mathrm{O}(0.41 \mathrm{~mL}, 3.24$ mmol) were reacted in $\mathrm{CH}_{2} \mathrm{Cl}_{2}(20 \mathrm{~mL})$ to afford $\mathbf{8 b}$ as a white solid in $62 \%$ yield (548 mg, $1.35 \mathrm{mmol}) .{ }^{1} \mathrm{H}$ NMR $\left(500 \mathrm{MHz}, \mathrm{CDCl}_{3}\right) \delta 7.42\left(\mathrm{dd}, J=8.7,1.6 \mathrm{~Hz}, 2 \mathrm{H}, \mathrm{H}_{5^{\prime}}\right.$ ), $7.02\left(\mathrm{t}, J=8.7 \mathrm{~Hz}, 2 \mathrm{H}, \mathrm{H}_{6^{\prime}}\right), 5.20\left(\mathrm{t}, J=8.4 \mathrm{~Hz}, 1 \mathrm{H}, \mathrm{H}_{1}\right)$, $5.00-4.91\left(2 \mathrm{H}, \mathrm{H}_{2}+\mathrm{H}_{4}\right), 4.81\left(\mathrm{~d}, J=6.6 \mathrm{~Hz}, 1 \mathrm{H}, \mathrm{H}_{3}\right), 4.54$ $\left(\mathrm{d}, J=1.6 \mathrm{~Hz}, 2 \mathrm{H}, \mathrm{H}_{1^{\prime}}\right), 4.16\left(\mathrm{dd}, J=11.9,5.0 \mathrm{~Hz}, 1 \mathrm{H}, \mathrm{H}_{5}\right)$, 3.43 (dd, $\left.J=11.9,8.4 \mathrm{~Hz}, 1 \mathrm{H}, \mathrm{H}_{5}\right), 2.06\left(\mathrm{~s}, 6 \mathrm{H}, \mathrm{CH}_{3(\mathrm{OAc})}\right)$, $2.05\left(\mathrm{~s}, 3 \mathrm{H}, \mathrm{CH}_{3(\mathrm{OAc})}\right) \cdot{ }^{13} \mathrm{C}\left\{{ }^{1} \mathrm{H}\right\}$ NMR $\left(126 \mathrm{MHz}, \mathrm{CDCl}_{3}\right) \delta$ $170.1(\mathrm{C}=0), 169.9(\mathrm{C}=0), 169.5(\mathrm{C}=0), 162.8(\mathrm{~d}, J=$ $250.0 \mathrm{~Hz}, \mathrm{C}_{7^{\prime}}$ ), 133.8 (d, $\left.J=8.4 \mathrm{~Hz}, \mathrm{C}_{5^{\prime}}\right), 118.4$ (d, $J=3.4$ $\mathrm{Hz}, \mathrm{C}_{4^{\prime}}$ ), 115.8 (d, $\left.J=22.2 \mathrm{~Hz}, \mathrm{C}_{6^{\prime}}\right), 98.5\left(\mathrm{C}_{1}\right), 86.0\left(\mathrm{C}_{2^{\prime}}\right)$, $83.4\left(\mathrm{C}_{3^{\prime}}\right), 71.3\left(\mathrm{C}_{3}\right), 70.6\left(\mathrm{C}_{2}\right), 68.9\left(\mathrm{C}_{4}\right), 62.1\left(\mathrm{C}_{5}\right), 56.5$ $\left(\mathrm{C}_{1^{\prime}}\right), 20.9,20.8\left(\mathrm{CH}_{3(\mathrm{OAc})}\right) .{ }^{19} \mathrm{~F}\left\{{ }^{1} \mathrm{H}\right\}$ NMR $(471 \mathrm{MHz}$, $\left.\mathrm{CDCl}_{3}\right) \delta$-110.2. HRMS (EI) $\mathrm{m} / \mathrm{z}$ : $[\mathrm{M}+\mathrm{Na}]^{+}$Calcd for $\mathrm{C}_{20} \mathrm{H}_{21} \mathrm{O}_{8} \mathrm{NaF}$ 431.1118; Found 431.1122. $[\alpha]^{20} \mathrm{D}=-28(\mathrm{c}$ 0.80, $\mathrm{CHCl}_{3}$ ). m.p. $85{ }^{\circ} \mathrm{C}$. IR (neat, $\mathrm{cm}^{-1}$ ) 3478, 2960, 2239, 1754, 1602, 1508, 1433, 1224, 1077, 840, 757.

Synthesis of 2-(but-2-yn-1-yl)- $\beta$-D-xylopyranoside 9a. According to the general procedure, acetylated xylose derivative 8a (2.87 g, $8.75 \mathrm{mmol}$ ) and $\mathrm{Na}(5 \mathrm{mg})$ were reacted in methanol $(20 \mathrm{~mL})$ to afford product $9 \mathbf{a}$ as a white solid in quantitative yield $(1.76 \mathrm{~g}, 8.75 \mathrm{mmol}) .{ }^{1} \mathrm{H}$ NMR (500 MHz, CD $\left.{ }_{3} \mathrm{OD}\right) \delta 4.41\left(\mathrm{~d}, J=7.5 \mathrm{~Hz}, 1 \mathrm{H}, \mathrm{H}_{1}\right)$, 4.31 (dq, $J=15.2,2.3 \mathrm{~Hz}, \mathrm{H}_{1^{\prime}}$ ), 3.87 (dd, $J=11.5,5.3 \mathrm{~Hz}$, $\left.1 \mathrm{H}, \mathrm{H}_{5}\right), 3.51-3.47\left(\mathrm{~m}, 1 \mathrm{H}, \mathrm{H}_{4}\right), 3.33-3.31\left(\mathrm{~m}, 1 \mathrm{H}, \mathrm{H}_{3}\right)$, 3.23-3.14 $\left(2 \mathrm{H}, \mathrm{H}_{2}+\mathrm{H}_{5}\right), 1.84\left(\mathrm{t}, J=2.3 \mathrm{~Hz}, 3 \mathrm{H}, \mathrm{H}_{4^{\prime}}\right)$. ${ }^{13} \mathrm{C}\left\{{ }^{1} \mathrm{H}\right\}$ NMR $\left(126 \mathrm{MHz}, \mathrm{CD}_{3} \mathrm{OD}\right) \delta 102.6\left(\mathrm{C}_{1}\right), 83.6\left(\mathrm{C}_{2^{\prime}}\right)$, $77.7\left(\mathrm{C}_{3}\right), 75.2\left(\mathrm{C}_{3^{\prime}}\right), 74.7\left(\mathrm{C}_{2}\right), 71.2\left(\mathrm{C}_{4}\right), 66.9\left(\mathrm{C}_{5}\right), 57.1$ $\left(\mathrm{C}_{1^{\prime}}\right), 3.1\left(\mathrm{C}_{4^{\prime}}\right)$. HRMS (EI) m/z: $[\mathrm{M}+\mathrm{Na}]^{+}$Calcd for $\mathrm{C}_{9} \mathrm{H}_{14} \mathrm{O}_{5} \mathrm{Na}$ 225.0739; Found 225.0742. $[\alpha]^{20}{ }_{\mathrm{D}}=-54(\mathrm{c}$ 0.60, $\mathrm{CH}_{3} \mathrm{OH}$ ); m.p. $152{ }^{\circ} \mathrm{C}$; IR (neat, $\mathrm{cm}^{-1}$ ) 3385, 2959, 2925, 2869, 1435, 1359, 1243, 1164, 1109, 1046, 975.

Synthesis of 2-((3-(4-fluorophenyl) prop-2-yn-1-yl)- $\beta$ - $D$ xylopyranoside $\mathbf{9 b}$. According to the general procedure, acetylated xylose derivative $\mathbf{8 b}(260 \mathrm{mg}, 0.63 \mathrm{mmol})$ and $\mathrm{Na}(2 \mathrm{mg})$ were reacted in methanol $(20 \mathrm{~mL})$ to afford product $\mathbf{9 b}$ as a white solid in quantitative yield (176 mg, $0.63 \mathrm{mmol}) .{ }^{1} \mathrm{H}$ NMR $\left(600 \mathrm{MHz}, \mathrm{CD}_{3} \mathrm{OD}\right) \delta$ 7.46-7.43 (m, 2H, $\left.\mathrm{H}_{5^{\prime}}\right), 7.07\left(\mathrm{t}, J=8.8 \mathrm{~Hz}, 2 \mathrm{H}, \mathrm{H}_{6^{\prime}}\right), 4.58$ $\left(\mathrm{d}, J=15.8 \mathrm{~Hz}, 1 \mathrm{H}, \mathrm{H}_{1^{\prime}}\right), 4.53\left(\mathrm{~d}, J=15.7 \mathrm{~Hz}, 1 \mathrm{H}, \mathrm{H}_{1^{\prime}}\right), 4.46$ (d, $J=7.4 \mathrm{~Hz}, 1 \mathrm{H}, \mathrm{H}_{1}$ ), 3.89 (dd, $J=11.5,5.3 \mathrm{~Hz}, 1 \mathrm{H}, \mathrm{H}_{5}$ ), 3.50 (ddd, $\left.J=10.1,8.7,5.3 \mathrm{~Hz}, 1 \mathrm{H}, \mathrm{H}_{4}\right), 3.34\left(\mathrm{~m}, 1 \mathrm{H}, \mathrm{H}_{3}\right.$ ), 3.24-3.20 (2H, $\left.\mathrm{H}_{2}+\mathrm{H}_{5}\right) \cdot{ }^{13} \mathrm{C}\left\{{ }^{1} \mathrm{H}\right\}$ NMR $\left(151 \mathrm{MHz}, \mathrm{CD}_{3} \mathrm{OD}\right)$ $\delta 164.9\left(\mathrm{~d}, J=248.5 \mathrm{~Hz}, \mathrm{C}_{7^{\prime}}\right), 134.9\left(\mathrm{~d}, J=8.7 \mathrm{~Hz}, \mathrm{C}_{5^{\prime}}\right.$ ), $120.2\left(\mathrm{C}_{4^{\prime}}\right), 116.6\left(\mathrm{~d}, J=22.5 \mathrm{~Hz}, \mathrm{C}_{6^{\prime}}\right), 103.0\left(\mathrm{C}_{1}\right), 86.2$ $\left(\mathrm{C}_{2^{\prime}}\right), 85.2\left(\mathrm{C}_{3^{\prime}}\right), 77.6\left(\mathrm{C}_{3}\right), 74.7\left(\mathrm{C}_{2}\right), 71.1\left(\mathrm{C}_{4}\right), 66.9\left(\mathrm{C}_{5}\right)$, $57.2\left(\mathrm{C}_{1}\right) .{ }^{19} \mathrm{~F}\left\{{ }^{1} \mathrm{H}\right\}$ NMR $\left(235 \mathrm{MHz}, \mathrm{CD}_{3} \mathrm{OD}\right) \delta$-112.9. HRMS (EI) m/z: $[\mathrm{M}+\mathrm{Na}]^{+}$Calcd for $\mathrm{C}_{14} \mathrm{H}_{15} \mathrm{O}_{5} \mathrm{NaF}$ 305.0801; Found 305.0803. $[\alpha]^{20}{ }_{\mathrm{D}}=-29\left(c 0.65, \mathrm{CH}_{3} \mathrm{OH}\right)$. m.p. $181{ }^{\circ} \mathrm{C}$. IR (neat, $\mathrm{cm}^{-1}$ ) 3386, 2926, 2868, 2780, 1597, 1510, 1361, 1234, 1159, 1046, 977, 837.

Synthesis of 2-(but-2-yn-1-yl)-2,3,4-tri-O-methyl- $\beta$-Dxylopyranoside 5a. According to the general procedure, unprotected D-xylosides 9a (753.7 $\mathrm{mg}, 3.73 \mathrm{mmol}$ ), $\mathrm{Ag}_{2} \mathrm{O}$ (3.12 g, $\left.1.2 \mathrm{mmol} / \mathrm{OH}\right), \mathrm{Me}_{2} \mathrm{~S}(0.1 \mathrm{~mL}, \mathrm{ca})$ and me- 
thyl iodide (12 $\mathrm{mL}, 186 \mathrm{mmol})$, were reacted in acetonitrile $(60 \mathrm{~mL})$, to afford product $\mathbf{5 a}$ as a white solid in 95 $\%$ yield (856 mg, $3.51 \mathrm{mmol}) .{ }^{1} \mathrm{H}$ NMR $\left(600 \mathrm{MHz}, \mathrm{CDCl}_{3}\right)$ $\delta 4.38\left(\mathrm{~d}, J=7.2 \mathrm{~Hz}, 1 \mathrm{H}, \mathrm{H}_{1}\right), 4.24(\mathrm{dq}, J=15.2,2.4 \mathrm{~Hz}$, $\left.2 \mathrm{H}, \mathrm{H}_{1^{\prime}}\right), 3.90\left(\mathrm{dd}, J=11.6,5.1 \mathrm{~Hz}, 1 \mathrm{H}, \mathrm{H}_{5}\right), 3.53(\mathrm{~s}, 3 \mathrm{H}$, $\left.\mathrm{OCH}_{3}\right), 3.50\left(\mathrm{~s}, 3 \mathrm{H}, \mathrm{OCH}_{3}\right), 3.40\left(\mathrm{~s}, 3 \mathrm{H}, \mathrm{OCH}_{3}\right), 3.17-3.18$ $\left(\mathrm{m}, 1 \mathrm{H}, \mathrm{H}_{4}\right), 3.11-3.05\left(2 \mathrm{H}, \mathrm{H}_{2}+\mathrm{H}_{5}\right), 2.95$ (dd, $J=8.8,7.2$ $\left.\mathrm{Hz}, 1 \mathrm{H}, \mathrm{H}_{3}\right), 1.79\left(\mathrm{t}, J=2.3 \mathrm{~Hz}, 3 \mathrm{H}, \mathrm{H}_{4^{\prime}}\right) .{ }^{13} \mathrm{C}\left\{{ }^{1} \mathrm{H}\right\} \mathrm{NMR}$ $\left(151 \mathrm{MHz}, \mathrm{CDCl}_{3}\right) \delta 101.4\left(\mathrm{C}_{1}\right), 84.9\left(\mathrm{C}_{3}\right), 83.0\left(\mathrm{C}_{2}\right), 82.9$ $\left(\mathrm{C}_{2^{\prime}}\right), 79.3\left(\mathrm{C}_{4}\right), 74.2\left(\mathrm{C}_{3^{\prime}}\right), 63.1\left(\mathrm{C}_{5}\right), 60.6\left(\mathrm{OCH}_{3}\right), 60.3$ $\left(\mathrm{OCH}_{3}\right), 58.6\left(\mathrm{OCH}_{3}\right), 56.3\left(\mathrm{C}_{1^{\prime}}\right), 3.7\left(\mathrm{C}_{4^{\prime}}\right)$. HRMS (EI) m/z: $[\mathrm{M}+\mathrm{Na}]^{+}$Calcd for $\mathrm{C}_{12} \mathrm{H}_{20} \mathrm{O}_{5} \mathrm{Na}$ 267.1208; Found 267.1213. $[\alpha]^{20} \mathrm{D}=-49\left(c 1.2, \mathrm{CHCl}_{3}\right) \cdot$ m.p. $65^{\circ} \mathrm{C}$.

Synthesis of 2-(3-(4-fluorophenyl)prop-2-yn-1-yl)-2,3,4tri-O-methyl- $\beta$-D-xylopyranoside $\mathbf{5 b}$. According to the general procedure, unprotected D-xyloside $9 \mathbf{b}(280 \mathrm{mg}$, $1 \mathrm{mmol}$ ), $\mathrm{Ag}_{2} \mathrm{O}$ (1.4 g, $\left.1.2 \mathrm{mmol} / \mathrm{OH}\right), \mathrm{Me}_{2} \mathrm{~S}(0.1 \mathrm{~mL}$, ca) and methyl iodide $(3.2 \mathrm{~mL}, 50 \mathrm{mmol})$, were reacted in acetonitrile $(20 \mathrm{~mL})$, to afford product $\mathbf{5 b}$ as a white solid in $97 \%$ yield (313 mg, $0.96 \mathrm{mmol}$ ). ${ }^{1} \mathrm{H}$ NMR (500 $\left.\mathrm{MHz}, \mathrm{CDCl}_{3}\right) \delta 7.40\left(\mathrm{~m}, 2 \mathrm{H}, \mathrm{H}_{5}{ }^{\prime}\right), 6.99\left(\mathrm{~m}, 2 \mathrm{H}, \mathrm{H}_{6}{ }^{\prime}\right), 4.55$ $\left(\mathrm{m}, 2 \mathrm{H}, \mathrm{H}_{1^{\prime}}\right), 4.52\left(\mathrm{~d}, J=7.7 \mathrm{~Hz}, 1 \mathrm{H}, \mathrm{H}_{1}\right), 3.99(\mathrm{dd}, J=$ 11.6, $\left.5.0 \mathrm{~Hz}, 1 \mathrm{H}, \mathrm{H}_{5}\right), 3.59\left(\mathrm{~s}, 3 \mathrm{H}, \mathrm{OCH}_{3}\right), 3.58(\mathrm{~s}, 3 \mathrm{H}$, $\left.\mathrm{OCH}_{3}\right), 3.46\left(\mathrm{~s}, 3 \mathrm{H}, \mathrm{OCH}_{3}\right), 3.27\left(\mathrm{~m}, 1 \mathrm{H}, \mathrm{H}_{4}\right), 3.21-3.14$ $\left(2 \mathrm{H}, \mathrm{H}_{2}+\mathrm{H}_{5}\right), 3.05\left(\mathrm{dd}, J=8.7,7.1 \mathrm{~Hz}, 1 \mathrm{H}, \mathrm{H}_{3}\right) .{ }^{13} \mathrm{C}\left\{{ }^{1} \mathrm{H}\right\}$ NMR (126 MHz, CDCl $\left.{ }_{3}\right) 162.7\left(\mathrm{~d}, J=249.7 \mathrm{~Hz}, \mathrm{C}_{7^{\prime}}\right), 133.8$ (d, $\left.J=8.4 \mathrm{~Hz}, \mathrm{C}_{5^{\prime}}\right), 118.7\left(\mathrm{~d}, J=3.7 \mathrm{~Hz}, \mathrm{C}_{4^{\prime}}\right), 115.7(\mathrm{~d}, J=$ $\left.22.1 \mathrm{~Hz}, \mathrm{C}_{6^{\prime}}\right), 101.7\left(\mathrm{C}_{1}\right), 85.6\left(\mathrm{C}_{2^{\prime}}\right), 84.8\left(\mathrm{C}_{3}\right), 84.0\left(\mathrm{C}_{3^{\prime}}\right)$, $83.0\left(\mathrm{C}_{2}\right), 79.4\left(\mathrm{C}_{4}\right), 63.2\left(\mathrm{C}_{5}\right), 60.7\left(\mathrm{OCH}_{3}\right), 60.4\left(\mathrm{OCH}_{3}\right)$, $58.7\left(\mathrm{OCH}_{3}\right), 56.5\left(\mathrm{C}_{1^{\prime}}\right) .{ }^{19} \mathrm{~F}\left\{{ }^{1} \mathrm{H}\right\}$ NMR $\left(235 \mathrm{MHz}, \mathrm{CDCl}_{3}\right) \delta$ -110.5. HRMS (EI) m/z: $[\mathrm{M}+\mathrm{Na}]^{+}$Calcd for $\mathrm{C}_{17} \mathrm{H}_{21} \mathrm{O}_{5} \mathrm{NaF}$ 347.1271; Found 347.1264. $[\alpha]^{20}{ }_{\mathrm{D}}=-47\left(\mathrm{c} 0.62, \mathrm{CHCl}_{3}\right)$. m.p. $85{ }^{\circ} \mathrm{C}$. IR (neat, $\mathrm{cm}^{-1}$ ) 3100, 3065, 2930, 2859, $2745,2222,1600,1506,1462,1368,1221,1096,890$, 637.

\section{Synthesis of disubstituted allenes $6 a, b$}

Synthesis of 2-(buta-1,2-dien-1-yl)-2,3,4-tri-O-methyl- $\beta$ $D$-xylopyranoside 6a. According to the general procedure, 5a (99.8 mg, $0.41 \mathrm{mmol})$, TMEDA $(0.05 \mathrm{~mL}, 0.45$ mmol), $s$-BuLi $(0.35 \mathrm{~mL}, 0.45 \mathrm{mmol})$ and $t$-BuOH $(0.6$ $\mathrm{mL}$ ) were reacted in $\mathrm{Et}_{2} \mathrm{O}(1 \mathrm{~mL}+0.8 \mathrm{~mL})$ to obtain the crude product $\mathbf{6 a}(99.8 \mathrm{mg})$ as a mixture of allenes $\mathbf{6 a}$ $(\mathrm{a} S) /(\mathrm{a} R)$ (65:35)/propargyl (91:9). The crude product was purified by flash column chromatography on silica gel $(10 \%$ EtOAc in PE) to afford the substituted allene as a colorless oil for analyses in $15 \%$ yield, due to its low stability over silica gel. Diastereoisomer $6 \mathbf{6 a}-(\mathrm{a} S):{ }^{1} \mathrm{H}$ NMR $\left(500 \mathrm{MHz}, \mathrm{CDCl}_{3}\right) \delta 6.55(\mathrm{tq}, J=5.2,2.2 \mathrm{~Hz}, 1 \mathrm{H}$, $\mathrm{H}_{1^{\prime}}$ ), 5.75 (qd, $\left.J=6.9,5.4 \mathrm{~Hz}, 1 \mathrm{H}, \mathrm{H}_{3^{\prime}}\right), 4.48(\mathrm{~d}, J=6.9 \mathrm{~Hz}$, $\left.1 \mathrm{H}, \mathrm{H}_{1}\right), 3.96\left(\mathrm{~m}, 1 \mathrm{H}, \mathrm{H}_{5}\right), 3.59\left(\mathrm{~s}, 3 \mathrm{H}, \mathrm{OCH}_{3}\right), 3.55(\mathrm{~s}, 3 \mathrm{H}$, $\left.\mathrm{OCH}_{3}\right), 3.45\left(\mathrm{~s}, 3 \mathrm{H}, \mathrm{OCH}_{3}\right), 3.25\left(\mathrm{~m}, 1 \mathrm{H}, \mathrm{H}_{3}\right), 3.17-3.08$ $\left(2 \mathrm{H}, \mathrm{H}_{2}+\mathrm{H}_{4}+\mathrm{H}_{5}\right), 1.75\left(\mathrm{t}, J=2.2 \mathrm{~Hz}, 3 \mathrm{H}, \mathrm{H}_{4^{\prime}}\right) .{ }^{13} \mathrm{C}\left\{{ }^{1} \mathrm{H}\right\}$ NMR (126 MHz, $\left.\mathrm{CDCl}_{3}\right) \delta 194.1\left(\mathrm{C}_{2^{\prime}}\right), 117.9\left(\mathrm{C}_{1^{\prime}}\right), 101.9$ $\left(\mathrm{C}_{3^{\prime}}\right), 101.3\left(\mathrm{C}_{1}\right), 85.0\left(\mathrm{C}_{3}\right), 82.7\left(\mathrm{C}_{2}\right), 79.3\left(\mathrm{C}_{4}\right), 63.3\left(\mathrm{C}_{5}\right)$, 60.7, 60.5, $58.7\left(\mathrm{OCH}_{3}\right), 16.6\left(\mathrm{C}_{4^{\prime}}\right)$. Diastereoisomer 6a$(\mathrm{a} R):{ }^{1} \mathrm{H}$ NMR $\left(500 \mathrm{MHz}, \mathrm{CDCl}_{3}\right) \delta 6.55(\mathrm{tq}, J=5.2,2.2$
$\mathrm{Hz}, 1 \mathrm{H}, \mathrm{H}_{1^{\prime}}$ ), $5.83\left(\mathrm{qd}, J=6.9,5.4 \mathrm{~Hz}, 1 \mathrm{H}, \mathrm{H}_{3^{\prime}}\right), 4.51(\mathrm{~d}, J=$ $\left.6.9 \mathrm{~Hz}, 1 \mathrm{H}, \mathrm{H}_{1}\right), 3.99\left(\mathrm{~m}, 1 \mathrm{H}, \mathrm{H}_{5}\right), 3.59\left(\mathrm{~s}, 3 \mathrm{H}, \mathrm{OCH}_{3}\right), 3.56$ $\left(\mathrm{s}, 3 \mathrm{H}, \mathrm{OCH}_{3}\right), 3.45\left(\mathrm{~s}, 3 \mathrm{H}, \mathrm{OCH}_{3}\right), 3.25\left(\mathrm{~m}, 1 \mathrm{H}, \mathrm{H}_{3}\right), 3.17-$ $\left.3.08\left(2 \mathrm{H}, \mathrm{H}_{2}+\mathrm{H}_{4}+\mathrm{H}_{5}\right), 1.77\left(\mathrm{t}, J=2.2 \mathrm{~Hz}, 3 \mathrm{H}, \mathrm{H}_{4}\right)^{\prime}\right)$. ${ }^{13} \mathrm{C}\left\{{ }^{1} \mathrm{H}\right\}$ NMR $\left(126 \mathrm{MHz}, \mathrm{CDCl}_{3}\right) \delta 194.6\left(\mathrm{C}_{2^{\prime}}\right), 118.1\left(\mathrm{C}_{1^{\prime}}\right)$, $101.9\left(\mathrm{C}_{3^{\prime}}\right), 101.7\left(\mathrm{C}_{1}\right), 85.0\left(\mathrm{C}_{3}\right), 82.7\left(\mathrm{C}_{2}\right), 79.3\left(\mathrm{C}_{4}\right)$, $63.3\left(\mathrm{C}_{5}\right), 60.7,60.5,58.7\left(\mathrm{OCH}_{3}\right), 16.9\left(\mathrm{C}_{4}\right) . \mathrm{IR}$ (neat, $\left.\mathrm{cm}^{-1}\right)$ 2972, 2931, 2836, 1970, 1736, 1460, 1383, 1324, $1165,1096,1020$.

Synthesis of 2-(3-(4-fluorophenyl)propa-1,2-dien-1-yl)2,3,4-tri-O-methyl- $\beta$-D-xylopyranoside $\mathbf{6 b}$. To a solution of $\mathbf{5 b}(98.7 \mathrm{mg}, 0.31 \mathrm{mmol})$ in THF $(1 \mathrm{~mL})$ at $-78{ }^{\circ} \mathrm{C}$ was added $n$-BuLi $(0.18 \mathrm{~mL}, 0.37 \mathrm{mmol})$. The resulting mixture was stirred at $-78{ }^{\circ} \mathrm{C}$ for $15 \mathrm{~min}$ then warmed to $40{ }^{\circ} \mathrm{C}$ and stirred for $25 \mathrm{~min}$. Then, a $\mathrm{HCl}\left(1 \mathrm{M}\right.$ in $\left.\mathrm{H}_{2} \mathrm{O}\right)$ solution was added dropwise. The reaction mixture was allowed to warm to room temperature and diluted with diethyl ether and water. The two phases were separated and the aqueous phase was extracted again with diethylether. The combined organic extracts were washed with $10 \% \mathrm{NaHCO}_{3}$ and brine, dried over $\mathrm{MgSO}_{4}$, filtered and concentrated under reduced pressure to afford the crude product $(95.4 \mathrm{mg}$ ) as a mixture of allenes $\mathbf{6 b}$ $(\mathrm{a} S) /(\mathrm{a} R)$ (60:40)/propargyl (93:7). The allenes 6b were not isolated as pure compounds, due to their low stability over silica gel or alumina, but were fully characterized in solution by multinuclear NMR spectroscopy. Diastereoisomer 6b-(aS): ${ }^{1} \mathrm{H}$ NMR (500 $\left.\mathrm{MHz}, \mathrm{CDCl}_{3}\right) \delta 7.34\left(\mathrm{~m}, 2 \mathrm{H}, \mathrm{H}_{5^{\prime}}\right), 7.01\left(3 \mathrm{H}, \mathrm{H}_{1^{\prime}}+\mathrm{H}_{6^{\prime}}\right), 6.66$ $\left(\mathrm{d}, \mathrm{J}=5.4 \mathrm{~Hz}, 1 \mathrm{H}, \mathrm{H}_{3^{\prime}}\right), 4.54\left(\mathrm{~d}, \mathrm{~J}=7.1 \mathrm{~Hz}, 1 \mathrm{H}, \mathrm{H}_{1}\right), 3.85$ (dd, J = 11.8, $5.1 \mathrm{~Hz}, 1 \mathrm{H}, \mathrm{H}_{5}$ ), 3.59 (s, $3 \mathrm{H}, \mathrm{OCH}_{3}$ ), 3.58 (s, $\left.3 \mathrm{H}, \mathrm{OCH}_{3}\right), 3.44\left(\mathrm{~s}, 3 \mathrm{H}, \mathrm{OCH}_{3}\right), 3.27\left(\mathrm{~m}, 1 \mathrm{H}, \mathrm{H}_{4}\right), 3.17-$ $3.13\left(2 \mathrm{H}, \mathrm{H}_{2}+\mathrm{H}_{3}\right), 2.99$ (dd, $\left.\mathrm{J}=11.8,9.6 \mathrm{~Hz}, 1 \mathrm{H}, \mathrm{H}_{5}\right)$. ${ }^{13} \mathrm{C}\left\{{ }^{1} \mathrm{H}\right\}$ NMR $\left(126 \mathrm{MHz}, \mathrm{CDCl}_{3}\right) \delta 195.5(\mathrm{~d}, \mathrm{~J}=2.7 \mathrm{~Hz}$, $\mathrm{C}_{2^{\prime}}$ ), $163.7\left(\mathrm{~d}, \mathrm{~J}=249.7 \mathrm{~Hz}, \mathrm{C}_{7^{\prime}}\right), 133.9\left(\mathrm{C}_{1^{\prime}}\right), 130.6(\mathrm{~d}, \mathrm{~J}=$ $\left.3.3 \mathrm{~Hz}, \mathrm{C}_{4^{\prime}}\right), 129.3\left(\mathrm{~d}, \mathrm{~J}=8.1 \mathrm{~Hz}, \mathrm{C}_{5^{\prime}}\right), 121.8\left(\mathrm{C}_{1}\right), 115.7(\mathrm{~d}$, $\left.\mathrm{J}=22.0 \mathrm{~Hz}, \mathrm{C}_{6^{\prime}}\right), 107.4\left(\mathrm{C}_{3^{\prime}}\right) 85.1\left(\mathrm{C}_{3}\right), 82.7\left(\mathrm{C}_{2}\right), 79.3\left(\mathrm{C}_{4}\right)$, $63.3\left(\mathrm{C}_{5}\right), 60.8,58.8,58.7\left(\mathrm{OCH}_{3}\right) .{ }^{19} \mathrm{~F}\left\{{ }^{1} \mathrm{H}\right\}$ NMR (471 $\left.\mathrm{MHz}, \mathrm{CDCl}_{3}\right) \delta$-113.7. Diastereoisomer $6 \mathbf{b}-(\mathrm{a} R):{ }^{1} \mathrm{H}$ NMR $\left(500 \mathrm{MHz}, \mathrm{CDCl}_{3}\right) \delta 7.34\left(\mathrm{~m}, 2 \mathrm{H}, \mathrm{H}_{5^{\prime}}\right), 7.01\left(3 \mathrm{H}, \mathrm{H}_{1^{\prime}}+\mathrm{H}_{6^{\prime}}\right)$, 7.42 (dd, J = 8.8, $\left.5.4 \mathrm{~Hz}, 1 \mathrm{H}, \mathrm{H}_{3^{\prime}}\right), 6.75(\mathrm{~d}, \mathrm{~J}=5.4 \mathrm{~Hz}, 1 \mathrm{H}$, $\left.\mathrm{H}_{1^{\prime}}\right), 4.58\left(\mathrm{~d}, \mathrm{~J}=6.5 \mathrm{~Hz}, 1 \mathrm{H}, \mathrm{H}_{1}\right), 4.00(\mathrm{dd}, \mathrm{J}=11.8,5.3 \mathrm{~Hz}$, $\left.1 \mathrm{H}, \mathrm{H}_{5}\right), 3.59\left(\mathrm{~s}, 3 \mathrm{H}, \mathrm{OCH}_{3}\right), 3.58\left(\mathrm{~s}, 3 \mathrm{H}, \mathrm{OCH}_{3}\right), 3.41(\mathrm{~s}$, $\left.3 \mathrm{H}, \mathrm{OCH}_{3}\right), 3.27\left(\mathrm{~m}, 1 \mathrm{H}, \mathrm{H}_{4}\right), 3.17-3.13\left(3 \mathrm{H}, \mathrm{H}_{2}+\mathrm{H}_{3}+\mathrm{H}_{5}\right)$. ${ }^{13} \mathrm{C}\left\{{ }^{1} \mathrm{H}\right\}$ NMR $\left(126 \mathrm{MHz}, \mathrm{CDCl}_{3}\right) \delta 194.8(\mathrm{~d}, \mathrm{~J}=2.7 \mathrm{~Hz}$, $\left.\mathrm{C}_{2^{\prime}}\right), 161.8\left(\mathrm{~d}, \mathrm{~J}=249.7 \mathrm{~Hz}, \mathrm{C}_{7^{\prime}}\right), 133.8\left(\mathrm{C}_{1^{\prime}}\right), 130.4(\mathrm{~d}, \mathrm{~J}=$ $\left.3.3 \mathrm{~Hz}, \mathrm{C}_{4^{\prime}}\right), 29.2\left(\mathrm{~d}, \mathrm{~J}=8.1 \mathrm{~Hz}, \mathrm{C}_{5^{\prime}}+\mathrm{C}_{9^{\prime}}\right), 121.7\left(\mathrm{C}_{1}\right), 115.8$ $\left(\mathrm{d}, \mathrm{J}=21.9 \mathrm{~Hz}, \mathrm{C}_{6^{\prime}}+\mathrm{C}_{8^{\prime}}\right), 107.4\left(\mathrm{C}_{3^{\prime}}\right), 84.8\left(\mathrm{C}_{3}\right), 82.7\left(\mathrm{C}_{2}\right)$, $79.2\left(\mathrm{C}_{4}\right), 63.3\left(\mathrm{C}_{5}\right), 60.7,58.8,58.7\left(\mathrm{OCH}_{3}\right) .{ }^{19} \mathrm{~F}\left\{{ }^{1} \mathrm{H}\right\} \mathrm{NMR}$ $\left(471 \mathrm{MHz}, \mathrm{CDCl}_{3}\right) \delta-113.5$.

\section{ASSOCIATED CONTENT}

\section{Supporting Information.}

Crystal data (CIF)

details on conformational studies of xylosides; details on determination of absolute configuration of $\mathbf{4 a}(\mathrm{a} S)$ by NOESY NMR experiments; spectra for all synthetic compounds; details for X-ray diffraction analysis; mechanistic study details for DFT calculation including Cartesian coordinates (PDF) 
"This material is available free of charge via the Internet at http://pubs.acs.org."

\section{AUTHOR INFORMATION}

\section{Corresponding Author}

*Email: yves.gimbert@univ-grenoble-alpes.fr

*Email: sylvain.gatard@univ-reims.fr

* Email: richard.plantier-royon@univ-reims.fr

*Email: florian.jaroschik@enscm.fr

\section{Author Contributions}

The manuscript was written through contributions of all authors.

\section{Notes}

The authors declare no conflict of interest.

\section{ACKNOWLEDGMENT}

Financial support from the CNRS and the University of Reims Champagne-Ardenne are gratefully acknowledged. We thank Carine Machado and Dominique Harakat for mass spectrometric analyses and we are grateful for the support of the technological platform PIAneT (ICMR, URCA) for the X-Ray Diffraction and NMR analyses. Part of this research was also undertaken on the MX2 beamline at the Australian Synchrotron, part of ANSTO, and made use of the Australian Cancer Research Foundation (ACRF) detector. The authors thank Maja Dunstan for her help collecting XRD data as well as Robert Gable and Louis Ricard for fruitful discussion. The authors acknowledge support from the ICMG Chemistry Nanobio Platform-PCECIC, Grenoble, for calculation facilities.

\section{REFERENCES}

(1) a) Schuster, H. F.; Coppola, G. M. Allenes in Organic Chemistry, Wiley-Interscience, New York, 1984; b) Krause, N.; Hashmi, A. S. K. Modern Allene Chemistry, Wiley-VCH, Weinheim, 2004; c) Aubert, C.; Fensterbank, L.; Garcia, P.; Malacria M.; Simonneau, A. Transition Metal Catalyzed Cycloisomerizations of 1,n-Allenynes and -Allenenes. Chem. Rev. 2011, 111, 1954-1993; d) Kitagaki, S.; Inagaki, F.; Mukai, C. [2+2+1] Cyclization of allenes. Chem Soc. Rev. 2014, 43, 2956-2978; e) Mascarenas, J. L.; Varela, I.; Lopez, F. Allenes and Derivatives in Gold(I)- and Platinum(II)-Catalyzed Formal Cycloadditions. Acc. Chem. Res. 2019, 52, 465-479.

(2) Reviews: a) Nedolya, N. A.; Tarasova, O.; Volostnykh, O. G.; Albanov, A. L.; Klyba, L. V.; Trofimov, B. A. Reactions of Lithiated Alkynes and Allenes with Isothiocyanates: A Simple and Efficient Synthesis of New Aryl- or Hetaryl-Substituted 3H-Azepines and 4,5-Dihydro-3H-azepines. Synthesis 2011, 2192-2204; b) Yu, S.; $\mathrm{Ma}, \mathrm{S}$. Allenes in Catalytic Asymmetric Synthesis and Natural Product Syntheses. Angew. Chem. Int. Ed. 2012, 51, 3074-3112; c) Adams, C. S.; Weatherly, C. D.; Burke, E. G.; Schomaker, J. M. The conversion of allenes to strained three-membered heterocycles. Chem. Soc. Rev. 2014, 43, 3136-3163; d) Neff, R. K.; Frantz, D. E. Recent applications of chiral allenes in axial-to-central chirality transfer reactions. Tetrahedron 2015, 71, 7-18; e) Reissig, H.-U.; Zimmer, R. Cyclizations of Alkoxyallenes: Mechanisms, Intermediates, Products - A Personal Account on Solved and Unsolved Problems with Unique Allene Building Blocks. Synthesis 2017, 49, 3291-3302; Recent original publications: f) Liu, H.-C.; Hu, Y. Z.; Wang, Z.-F.; Tao, H.-Y.; Wang, C.-J. Synergistic Cu/Pd-Catalyzed Asymmetric Allenylic Alkylation of Azomethine Ylides for the Construction of $\alpha$-Allene-Substituted Nonproteinogenic $\alpha$-Amino Acids. Chem. Eur. J. 2019, 25, 8681-8685; g) Peng, S.; Cao, S.; Sun, J. Gold-Catalyzed Regiodivergent $[2+2+2]$-Cycloadditions of Allenes with Triazines. Org. Lett. 2017, 19, 524-527; h) Wang, X.; Lu, M.; Su, Q.; Zhou, M.; Addepalli, Y.; Yao, W.; Wang, Z.; Lu, Y.
Phosphine-Catalyzed [4+2] Cycloadditions of Allenic Ketones: Enantioselective Synthesis of Functionalized Tetrahydropyridines. Chem. Asian J. 2019, 14, 3409-3413; i) Artigas, A.; Vila, J.; Lledó, A.; Solà, M.; Pla-Quintana, A.; Roglans, A. A Rh-Catalyzed Cycloisomerization/Diels-Alder Cascade Reaction of 1,5Bisallenes for the Synthesis of Polycyclic Heterocycles. Org. Lett. 2019, 21, 6608-6613.

(3) Reviews: a) Ogasawara, M. Catalytic enantioselective synthesis of axially chiral allenes. Tetrahedron: Asymmetry 2009, 20, 259-271; b) Chu, W.-D.; Zhang, Y.; Wang, J. Recent advances in catalytic asymmetric synthesis of allenes. Catal. Sci. Technol. 2017, 7, 4570-4579; Recent original publications: c) Vaithiyanathan, V.; Ravichandran, G.; Thirumailavan, V. Synthesis of chiral allene moiety from Morita-Baylis-Hillman adduct of isatin derivatives via Claisen rearrangement. Tetrahedron Lett. 2019, 60, 507-510; d) Rodriguez, R. I.; Ramirez, E.; FernandezSalas, J. A.; Sanchez-Obregon, R.; Yuste, F.; Aleman, J. Asymmetric [2,3]-Wittig Rearrangement: Synthesis of Homoallylic, Allenylic, and Enynyl $\alpha$-Benzyl Alcohols. Org. Lett. 2018, 20, 8047-8051; e) Zhang, P.; Huang, Q.; Cheng, Y.; Li, R.; Li, P.; Li, W. Remote Stereocontrolled Construction of Vicinal Axially Chiral Tetrasubstituted Allenes and Heteroatom-Functionalized Quaternary Carbon Stereocenters. Org. Lett. 2019, 21, 503-507; f) Cheng, X.; Wang, Z.; Quintanilla, C. D.; Zhang, L. Chiral Bifunctional Phosphine Ligand Enabling Gold-Catalyzed Asymmetric Isomerization of Alkyne to Allene and Asymmetric Synthesis of 2,5-Dihydrofuran. J. Am. Chem. Soc. 2019, 141, 3787-3791; g) Yamano, M. M.; Knapp, R. R.; Ngamnithiporn, A.; Ramirez, M.; Houk, K. N.; Stoltz, B. M.; Garg, N. K. Cycloadditions of Oxacyclic Allenes and a Catalytic Asymmetric Entryway to Enantioenriched Cyclic Allenes. Angew. Chem. Int. Ed. 2019, 58, $5653-5657$

(4) a) Harrington, P. E.; Murai, T.; Chu, C.; Tius, M. A. Asymmetric Cyclopentannelation: Camphor-Derived Auxiliary. J. Am. Chem. Soc. 2002, 124, 10091-10100; b) Hausherr, A.; Reissig, H.-U. Preparation of 3-Alkyl-Substituted 1-Alkoxyallenes - Synthetic and Mechanistic Aspects. Synthesis 2018, 50, 2546-2554; c) Hausherr, A.; Zimmer, R.; Reissig, H.-U. Additions of Carbohydrate-Derived Alkoxyallenes to Imines and Subsequent Reactions to Enantiopure 2,5-Dihydropyrrole Derivatives. Synthesis 2019, 51, 486499.

(5) a) Harrington, P. E.; Tius, M. A. Asymmetric Cyclopentannelation. Chiral Auxiliary on the Allene. Org. Lett. 2000, 2447 2450; b) Cai, S.; Kishan Gorityala, B.; Ma, J.; Leow, M. L.; Liu, X.-W. $[3+2]$ Cycloaddition on Carbohydrate Templates: Stereoselective Synthesis of Pyrrolidines. Org. Lett. 2011, 13, 1072-1075; c) Seghers, S.; Heugebaert, T. S. A.; Moens, M.; Sonck, J.; Thybaut, J. W.; Stevens, C. V. Design of a Mesoscale Continuous-Flow Route toward Lithiated Methoxyallene. ChemSusChem 2018, 11, 22482254; d) Lee, J.; Kang, S.; Kim, J.; Moon, D.; Rhee, Y. H. A Convergent Synthetic Strategy Towards Oligosaccharides Containing 2,3,6-Trideoxypyranoglycosides. Angew. Chem. Int. Ed. 2019, 58, $628-631$.

(6) a) Ochs, M.; Muzard, M.; Plantier-Royon, R.; Estrine, B.; Rémond, C. Enzymatic synthesis of alkyl $\beta$-D-xylosides and oligoxylosides from xylans and from hydrothermally pretreated wheat bran. Green Chem. 2011, 13, 2380-2388; b) Gatard, S.; Salmon, L.; Deraedt, C.; Astruc, D.; Bouquillon, S. Gold Nanoparticles Stabilized by Glycodendrimers: Synthesis and Application to the Catalytic Reduction of 4-Nitrophenol. Eur. J. Inorg. Chem. 2014, 2671 2677; c) Brusa, C.; Ochs, M.; Rémond, C.; Muzard, M.; PlantierRoyon, R. Chemoenzymatic synthesis of "click" xylosides and xylobiosides from lignocellulosic biomass. RSC Adv. 2014, 4, 9330-9338; d) Gatard, S.; Plantier-Royon,R.; Rémond, C.; Muzard, M.; Kowandy, C.; Bouquillon, S. Preparation of new $\beta$-D-xylosideand $\beta$-D-xylobioside-based ionic liquids through chemical and/or enzymatic reactions. Carbohydr. Res. 2017, 451, 72-80.

(7) For other examples of allenes incorporating a sugar part: a) Rochet, P.; Vatèle, J.-M.; Goré, J. An Efficient Synthesis of Enantiopure 1-Alkoxy-1,2-propadienes from Propargyl Bromide. Synthe- 
sis 1994, 795-799; b) Surivet, J.-P.; Goré, J.; Vatèle, J.-M. Total synthesis of (+)-goniodiol. Tetrahedron Lett. 1996, 37, 371-374; c) Mereyala, H. B.; Gurrala, S. R.; Mohan, S. K. Study of metal and acid catalysed deprotection of propargyl ethers of alcohols via their allenyl ethers. Tetrahedron 1999, 55, 11331-11342; d) HoffmannRöder, A.; Krause, N. Synthesis and Properties of Allenic Natural Products and Pharmaceuticals. Angew. Chem. Int. Ed. 2004, 43, 1196-1216; e) Banaag, A. R.; Tius, M. A. Traceless Chiral Auxiliaries for the Allene Ether Nazarov Cyclization. J. Org. Chem. 2008, 73, 8133-8141; f) Huang, X.; Xue, C.; Fu, C.; Ma, S. A concise construction of carbohydrate-tethered axially chiral allenes via copper catalysis. Org. Chem. Front. 2015, 2, 1040-1044.

(8) a) Ebringerova A.; Heinze, T. Xylan and xylan derivatives biopolymers with valuable properties, 1 . Naturally occurring xylans structures, isolation procedures and properties. Macromol. Rapid Commun. 2000, 21, 542-556.

(9) a) Koell, P.; Luetzen, A. D-xylose derived oxazolidin-2-ones as chiral auxiliaries in stereoselective alkylations. TetrahedronAsymmetry 1996, 7, 637-640; b) Koell, P.; Luetzen, A. D-Xylose derived oxazolidin-2-ones as chiral auxiliaries in stereoselective aldol reactions. Tetrahedron-Asymmetry 1997, 8, 1193-1206; c) Enholm, E. J.; Gallagher, M. E.; Jiang, S.; Batson, W. A. Free Radical Allyl Transfers Utilizing Soluble Non-Cross-Linked Polystyrene and Carbohydrate Scaffold Supports. Org. Lett. 2000, 2, 33553357; d) Enholm, E. J.; Cottone, J. S.; Allais, F. Highly Diastereoselective 5-Hexenyl Radical Cyclizations with Lewis Acids and Carbohydrate Scaffolds. F. Org. Lett. 2001, 3, 145-147; e) Enholm, E. J.; Bhardawaj, A. An asymmetric Kharasch reaction mediated by D-xylose: long range diastereocontrol. Tetrahedron Lett. 2003, 44, 3763-3765; f) Lu, Y. Just, G. Stereoselective synthesis of dithymidine phosphorothioates using D-xylose derived chiral auxiliaries. Tetrahedron 2001, 57, 1677-1687.

(10) a) Reich, H. J.; Holladay, J. E.; Walker, T. G.; Thompson, J. L. Solution Structure and Stereochemistry of Alkyl- and SilylSubstituted Allenyl-Propargyllithium Reagents. J. Am. Chem. Soc. 1999, 121, 9769-9780; b) Reich, H. J. What's Going on with These Lithium Reagents? J. Org. Chem. 2012, 77, 5471-5491; c) Reich, H. J. Role of Organolithium Aggregates and Mixed Aggregates in Organolithium Mechanisms. Chem. Rev. 2013, 113, 7130-7178.

(11) a) Thorsheim, K.; Siegbahn, A.; Johnsson, R. E.; Stålbrand, H.; Manner, S.; Widmalm, G.; Ellervik, U. Chemistry of xylopyranosides. Carbohydr. Res. 2015, 418, 65-88; b) Brusa, C.; Muzard, M.; Rémond, C.; Plantier-Royon, R. $\beta$-Xylopyranosides: synthesis and applications. RSC Adv. 2015, 5, 91026-91055.

(12) Sonogashira, K. Development of Pd-Cu catalyzed crosscoupling of terminal acetylenes with $\mathrm{sp} 2$-carbon halides. J. Organomet. Chem. 2002, 653, 46-49.

(13) a) Eliel, E. L.; Satici, H. Conformational Analysis of Cyclohexyl Silyl Ethers. J. Org. Chem. 1994, 59, 688-689; b) Broddefalk, J.; Bergquist, K.-E.; Kihlberg, J. Use of acid-labile protective groups for carbohydrate moieties in synthesis of glycopeptides related to type II collagen. Tetrahedron 1998, 54, 12047-12070; c) Marzabadi, C. H.; Anderson, J. E.; Gonzalez-Outeirino, J.; Gaffney, P. R. J.; White, C. G. H.; Tocher, D. A.; Todaro, L. J. Why Are Silyl Ethers Conformationally Different from Alkyl Ethers? Chair-Chair Conformational Equilibria in Silyloxycyclohexanes and Their Dependence on the Substituents on Silicon. The Wider Roles of Eclipsing, of 1,3-Repulsive Steric Interactions, and of Attractive Steric Interactions. J. Am. Chem. Soc. 2003, 125, 15163-15173; d) Heuckendorff, M.; Pedersen, C. M.; Bols, M. Rhamnosylation: Diastereoselectivity of Conformationally Armed Donors. J. Org. Chem. 2012, 77, 5559-5568; e) Bols, M.; Pedersen, C. M. Silyl-protective groups influencing the reactivity and selectivity in glycosylations. Beilstein J. Org. Chem. 2017, 13, 93-105.

(14) a) Cavigiolio, G.; Morgan, J. L.; Robinson, B. H.; Simpson, J. Fluorescent Sugar and Uridine Conjugates of 1,8-Naphthalimides with Methyl and Ferrocenyl Headgroups. Aust. J. Chem. 2004, 57, 885-894; b) Al-Mughaid, H.; Robertson, K. N.; Werner-Zwanziger, U.; Lumsden, M. D.; Cameron, T. S.; Grindley, T. B. 2-Propynyl 2,3,4,6-tetra-0-acetyl- $\alpha$-D-mannopyranoside. Acta Crystallogr. C 2011, C67, o60-063.

(15) Dreller, S.; Dyrbusch, M.; Hoppe, D. Synthesis of Enantiomerically Enriched Allenes via Chiral, Configurationally Stable 1Lithio-2-alkynyl Carbamates. Synlett 1991, 397-400.

(16) Bejjani, J.; Botuha, C.; Chemla, F.; Ferreira, F.; Magnus, S.; Pérez-Luna, A. Metallotropic Equilibrium and Configurational Stability of 3-Chloro-1-(trimethylsilyl)propargyl and -allenyl Metals: Comparative Study among Lithium, Titanium, and Zinc. Organometallics 2012, 31, 4876-4885.

(17) Lysek, R.; Krajewski, P.; Urbańczyk-Lipkowska, Z.; Furman, B.; Kałuża, Z.; Kozerski, L.; Chmielewski, M. Conformation of chiral alkoxyallenes by proton NMR spectroscopy. J. Chem. Soc. Perkin Trans. 2000, 1, 61-67.

(18) Mikami, K.; Yoshida, A. Dynamic Kinetic Protonation of Racemic Allenylmetal Species for the Asymmetric Synthesis of Allenic Esters. Angew. Chem. Int. Ed. Engl. 1997, 36, 858-860.

(19) Ferreira, F.; Denichoux, A.; Chemla, F.; Bejjani, J. Highly Diastereoselective Syntheses of Propargylic Acid and Homopropargylic Systems. Synlett 2004, 2051-2065.

(20) a) Reich, H. J.; Holladay, J. E.; Mason, J. D.; Sikorski, W. H. The Origin of Regioselectivity in an Allenyllithium Reagent. J. Am. Chem. Soc. 1995, 117, 12137-12150; b) Maercker, A.; Wunderlich, H.; Girreser, U. Polylithiumorganic compounds - 23. 3,4-Dilithio1,2-butadienes by addition of lithium metal to 1,4 unsymmetrically substituted butatrienes. Tetrahedron 1996, 52, 6149-6172.

(21) Chowdhury, M. A.; Reissig, H.-U. Syntheses of Highly Substituted Furan and Pyrrole Derivatives via Lithiated 3-Aryl-1methoxyallenes: Application to the Synthesis of Codonopsinine. Synlett 2006, 2383-2386.

(22) a) Runge, W. The Molecular Structure of Allenes and Ketenes, XI Semiempirical Calculations of ${ }^{1} \mathrm{H}$-Chemical Shifts of Allenes. Z. Naturforsch. B 1977, 32b, 1296-1303; b) Elsevier, C. J.; Meijer, J.; Tadema, G.; Vermeer, P.; Runge, W. The Molecular Structure of Allenes and Ketenes. Part 16. Phenyl Carbon Chemical Shifts of $\gamma$-Substituted Phenylallenes as a Probe for the Transmissions of Substituent Effects across the Allenic System. J. Chem. Soc. Perkin Trans. II 1983, 1093-1101.

(23) The lithium species under consideration may form aggregates in solution (see ref. 10 and 16), however, in this paper, only monomeric species will be considered.

(24) No significant difference was observed between $\mathrm{MeOH}$ and $t-\mathrm{BuOH}$ in a preliminary calculation, so the smaller alcohol was chosen to minimize an already cumbersome system.

(25) Ni, K.; Meng, L.-G.; Ruan, H.; Wang, L. Controllable chemoselectivity in the coupling of bromoalkynes with alcohols under visible-light irradiation without additives: synthesis of propargyl alcohols and $\alpha$-ketoesters. Chem. Commun. 2019, 55, 8438-8441.

(26) Wang, B.; Wang, X.; Yin, X.; Yu, W.; Liao, Y.; Ye, J.; Wang, M.; Liao, J. Cu-Catalyzed $\mathrm{S}_{\mathrm{N}} 2^{\prime}$ Substitution of Propargylic Phosphates with Vinylarene-Derived Chiral Nucleophiles: Synthesis of Chiral Allenes. Org. Lett. 2019, 21, 3913-3917.

(27) Aragão, D.; Aishima, J.; Cherukuvada, H.; Clarken, R.; Clift, M.; Cowieson, N. P.; Ericsson, D. J.; Gee, C. L.; Macedo, S.; Mudie, N.; Panjikar, S.; Price, J. R.; Riboldi-Tunnicliffe, A.; Rostan, R.; Williamson, R.; Caradoc-Davies, T. T. MX2: a high-flux undulator microfocus beamline serving both the chemical and macromolecular crystallography communities at the Australian Synchrotron. J. Synchrotron Radiat. 2018, 25, 885-891.

(28) Kováč, P. Alternative syntheses of methylated sugars: Part VIII. Methyl (methyl 3,4-di-O-methyl- $\alpha$-D-galactopyranosid)uronate. Carbohydr. Res. 1972, 22, 464-466. 


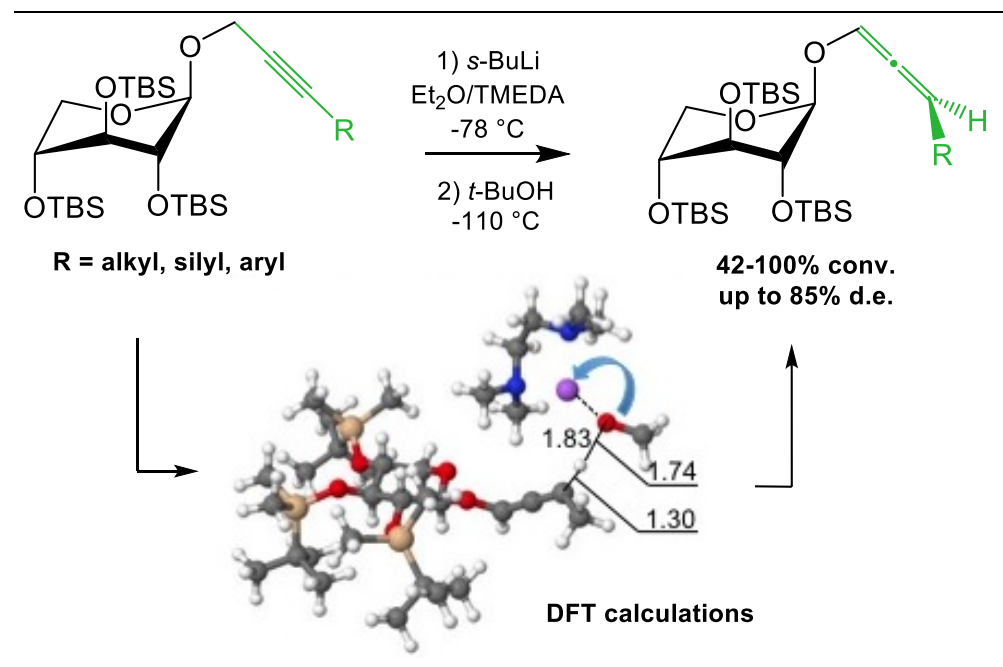

Insert Table of Contents artwork here 